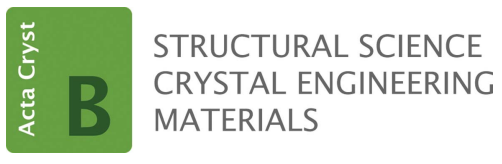

ISSN 2052-5206

Received 1 October 2021

Accepted 8 December 2021

Edited by J. Lipkowski, Polish Academy of Sciences, Poland

Keywords: mcalpineite; copper; tellurate; polytypes; crystal structure; 3D ED.

CCDC reference: 2110654

Supporting information: this article has supporting information at journals.iucr.org/b

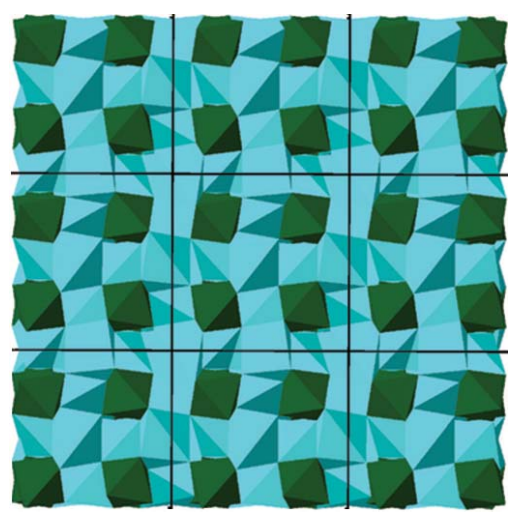

\section{Polytypism in mcalpineite: a study of natural and synthetic $\mathrm{Cu}_{3} \mathrm{TeO}_{6}$}

\author{
Owen P. Missen, ${ }^{\mathrm{a}, \mathrm{b} *}$ Stuart J. Mills, ${ }^{\mathrm{b}}$ Stefano Canossa, ${ }^{\mathrm{c}}$ Joke Hadermann, \\ Gwilherm Nénert, ${ }^{\mathrm{d}}$ Matthias Weil, ${ }^{\mathrm{e}}$ Eugen Libowitzky, ${ }^{\mathrm{f}}$ Robert M. Housley, ${ }^{\mathrm{g}}$ \\ Werner Artner, ${ }^{\text {h }}$ Anthony R. Kampf, ${ }^{i}$ Michael S. Rumsey, john Spratt, ${ }^{\text {, }}$ \\ Koichi Momma' and Maja A. Dunstan ${ }^{m}$
}

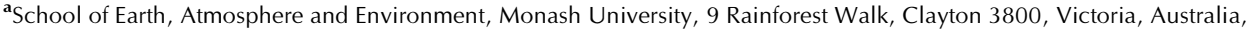

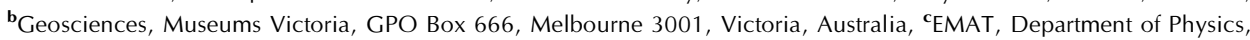
University of Antwerp, Groenenborgerlaan 171, 2020 Antwerpen, Belgium, dMalvern Panalytical B.V., Lelyweg 1, 7602

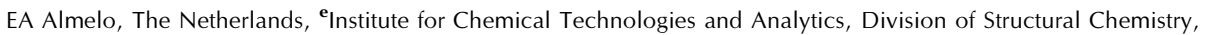
TU Wien, Getreidemarkt 9/164-SC, A-1060 Vienna, Austria, 'Institute for Mineralogy and Crystallography, Faculty of Geosciences, Geography and Astronomy, Universität Wien, Althanstr. 14, A-1090 Vienna, Austria, ${ }^{\mathbf{g}}$ Division of Geological and Planetary Sciences, California Institute of Technology, Pasadena, CA 91125, USA, 'hX-ray Center, TU Wien, Getreidemarkt 9, A-1060 Vienna, Austria, 'Mineral Sciences Department, Natural History Museum of Los Angeles County, 900 Exposition Boulevard, Los Angeles, CA 90007, USA, 'Department of Earth Sciences, Natural History Museum, Cromwell Road, London, SW7 5BD, UK, ${ }^{\mathbf{k}}$ Core Research Laboratories, Natural History Museum, 21 Cromwell Road, London, UK, SW7 5BD, 'National Museum of Nature and Science, 4-1-1 Amakubo, Tsukuba, Ibaraki 305-0005, Japan, and ${ }^{\mathbf{m}}$ School of Chemistry, University of Melbourne, Parkville, Victoria, 3010, Australia. *Correspondence e-mail: omissen@museum.vic.gov.au
\end{abstract}

Synthetic and naturally occurring forms of tricopper orthotellurate, $\mathrm{Cu}^{\mathrm{II}}{ }_{3} \mathrm{Te}^{\mathrm{VI}} \mathrm{O}_{6}$ (the mineral mcalpineite) have been investigated by $3 \mathrm{D}$ electron diffraction (3D ED), X-ray powder diffraction (XRPD), Raman and infrared (IR) spectroscopic measurements. As a result of the diffraction analyses, $\mathrm{Cu}_{3}{ }_{3}^{\mathrm{II}} \mathrm{Te}^{\mathrm{VI}} \mathrm{O}_{6}$ is shown to occur in two polytypes. The higher-symmetric $\mathrm{Cu}_{3}^{\mathrm{II}} \mathrm{Te}^{\mathrm{VI}} \mathrm{O}_{6}-1 C$ polytype is cubic, space group $I a \overline{3}$, with $a=9.537$ (1) $\AA$ and $V=867.4$ (3) $\AA^{3}$ as reported in previous studies. The $1 C$ polytype is a well characterized structure consisting of alternating layers of $\mathrm{Cu}^{\mathrm{II}} \mathrm{O}_{6}$ octahedra and both $\mathrm{Cu}^{\mathrm{II}} \mathrm{O}_{6}$ and $\mathrm{Te}^{\mathrm{VI}} \mathrm{O}_{6}$ octahedra in a patchwork arrangement. The structure of the lower-symmetric orthorhombic $\mathrm{Cu}_{3}{ }_{3} \mathrm{Te}^{\mathrm{VI}} \mathrm{O}_{6}-2 \mathrm{O}$ polytype was determined for the first time in this study by $3 \mathrm{D}$ $\mathrm{ED}$ and verified by Rietveld refinement. The $2 O$ polytype crystallizes in space

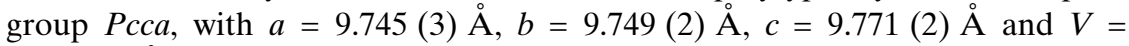
928.3 (4) $\AA^{3}$. High-precision XRPD data were also collected on $\mathrm{Cu}^{\mathrm{II}}{ }_{3} \mathrm{Te}^{\mathrm{VI}} \mathrm{O}_{6}-2 \mathrm{O}$ to verify the lower-symmetric structure by performing a Rietveld refinement. The resultant structure is identical to that determined by $3 \mathrm{D} \mathrm{ED}$, with unit-cell parameters $a=9.56157$ (19) $\AA, b=9.55853$ (11) $\AA, c=9.62891$ (15) $\AA$ and $V=$ $880.03(2) \AA^{3}$. The lower symmetry of the $2 O$ polytype is a consequence of a different cation ordering arrangement, which involves the movement of every second $\mathrm{Cu}^{\mathrm{II}} \mathrm{O}_{6}$ and $\mathrm{Te}^{\mathrm{VI}} \mathrm{O}_{6}$ octahedral layer by $(1 / 4,1 / 4,0)$, leading to an offset of $\mathrm{Te}^{\mathrm{VI}} \mathrm{O}_{6}$ and $\mathrm{Cu}^{\mathrm{II}} \mathrm{O}_{6}$ octahedra in every second layer giving an $A B A B^{*}$ stacking arrangement. Syntheses of $\mathrm{Cu}^{\mathrm{II}}{ }_{3} \mathrm{Te}^{\mathrm{VI}} \mathrm{O}_{6}$ showed that low-temperature $(473 \mathrm{~K})$ hydrothermal conditions generally produce the $2 O$ polytype. XRPD measurements in combination with Raman spectroscopic analysis showed that most natural mcalpineite is the orthorhombic $2 O$ polytype. Both XRPD and Raman spectroscopy measurements may be used to differentiate between the two polytypes of $\mathrm{Cu}_{3}^{\mathrm{II}} \mathrm{Te}^{\mathrm{VI}} \mathrm{O}_{6}$. In Raman spectroscopy, $\mathrm{Cu}_{3}{ }_{3} \mathrm{Te}^{\mathrm{VI}} \mathrm{O}_{6}-1 C$ has a single strong band around $730 \mathrm{~cm}^{-1}$, whereas $\mathrm{Cu}_{3}{ }_{3} \mathrm{Te}^{\mathrm{VI}} \mathrm{O}_{6}-2 O$ shows a broad double maximum with bands centred around 692 and $742 \mathrm{~cm}^{-1}$.

\section{Introduction}

$\mathrm{Cu}_{3}^{\mathrm{II}} \mathrm{Te}^{\mathrm{VI}} \mathrm{O}_{6}$ was first studied as a synthetic compound by Hostachy \& Coing-Boyat (1968) and subsequently by Falck et al. (1978). They both determined the crystal structure in the cubic space group Ia $\overline{3}$. Hostachy \& Coing-Boyat (1968) 
synthesized $\mathrm{Cu}_{3}^{\mathrm{II}} \mathrm{Te}^{\mathrm{VI}} \mathrm{O}_{6}$ in a solid-state reaction of $\mathrm{CuCO}_{3}$ and $\mathrm{Te}(\mathrm{OH})_{6}$, heated at $973 \mathrm{~K}$ in air for $36 \mathrm{~h}$, while Falck et al. (1978) synthesized their $\mathrm{Cu}_{3}{ }_{3}^{\mathrm{II}} \mathrm{Te}^{\mathrm{VI}} \mathrm{O}_{6}$ crystals at hightemperature $(973 \mathrm{~K})$ and under high-pressure (900 bar) hydrothermal conditions for one week using aqueous solutions of $\mathrm{CuSO}_{4}$ and $\mathrm{H}_{6} \mathrm{TeO}_{6}$. Subsequently, $\mathrm{Cu}_{3}{ }_{3} \mathrm{Te}^{\mathrm{VI}} \mathrm{O}_{6} \cdot \mathrm{H}_{2} \mathrm{O}$ was described as a mineral in 1994 by Roberts et al. (1994) and given the name mcalpineite. More recently, synthetic $\mathrm{Cu}_{3-}{ }_{3-}$ $\mathrm{Te}^{\mathrm{VI}} \mathrm{O}_{6}$ has been widely studied for its three-dimensional antiferromagnetic properties (e.g. Herak et al., 2005; Choi et al., 2008; Zhu et al., 2014; Chakraborty, 2019; Wang et al., 2019), while copper tellurium oxides in general are of interest for their magnetic properties (Norman, 2016, 2018; Inosov, 2018). Recently, we undertook a study to generate synthetic analogues of rare copper(II) tellurate minerals without known crystal structures, such as brumadoite $\left[\mathrm{Cu}_{3}\left(\mathrm{Te}^{\mathrm{VI}} \mathrm{O}_{4}\right)\right.$ $(\mathrm{OH})_{4} \cdot 5 \mathrm{H}_{2} \mathrm{O}$; Atencio et al. (2008)] and xocomecatlite $\left[\mathrm{Cu}_{3}\left(\mathrm{Te}^{\mathrm{VI}} \mathrm{O}_{4}\right)(\mathrm{OH})_{4}\right.$; Williams (1975)]. These experiments tended to produce phases with $\mathrm{X}$-ray powder diffraction (XRPD) patterns similar to $\mathrm{Cu}_{3}{ }_{3} \mathrm{Te}^{\mathrm{VI}} \mathrm{O}_{6}$, indicating the stability of phases with this formula. Our interest was piqued by the presence of additional minor XRPD reflections in the low-temperature (423-473 K) hydrothermally grown $\mathrm{Cu}_{3}^{\mathrm{II}} \mathrm{Te}^{\mathrm{VI}} \mathrm{O}_{6}$, which did not match the synthetic patterns for I-centred cubic $\mathrm{Cu}_{3}^{\mathrm{II}} \mathrm{Te}^{\mathrm{VI}} \mathrm{O}_{6}$, but were a good match for mcalpineite (Roberts et al., 1994).

Roberts et al. (1994) reported mcalpineite as copper tellurate monohydrate, $\mathrm{Cu}_{3}{ }_{3} \mathrm{Te}^{\mathrm{VI}} \mathrm{O}_{6} \cdot \mathrm{H}_{2} \mathrm{O}$, in a primitive unit-cell but otherwise undetermined cubic space group. This phase was first reported from two cotype localities: the McAlpine mine, California, USA $\left(37^{\circ} 45^{\prime} 58^{\prime \prime} \mathrm{N}, 120^{\circ} 15^{\prime} 9^{\prime \prime} \mathrm{W}\right)$ and the Centennial Eureka mine, Utah, USA ( $\left.39^{\circ} 56^{\prime} 36^{\prime \prime} \mathrm{N}, 112^{\circ} 7^{\prime} 19^{\prime \prime}\right)$. The latter mine is the type locality for six other $\mathrm{Cu}$-containing Te oxysalt minerals: eurekadumpite $\left[(\mathrm{Cu}, \mathrm{Zn})_{16}\left(\mathrm{Te}^{\mathrm{IV}} \mathrm{O}_{3}\right)_{2^{-}}\right.$ $\left(\mathrm{AsO}_{4}\right)_{3} \mathrm{Cl}(\mathrm{OH})_{18} \cdot 7 \mathrm{H}_{2} \mathrm{O}$; Pekov et al. (2011)], frankhawthorneite $\left[\mathrm{Cu}_{2} \mathrm{Te}^{\mathrm{VI}} \mathrm{O}_{4}(\mathrm{OH})_{2}\right.$; Roberts et al. (1995)], jensenite $\left[\mathrm{Cu}_{3} \mathrm{Te}^{6+} \mathrm{O}_{6} \cdot 2 \mathrm{H}_{2} \mathrm{O}\right.$; Roberts et al. (1996a)], juabite $\left[\mathrm{CaCu}_{10}\left(\mathrm{Te}^{\mathrm{IV}} \mathrm{O}_{3}\right)_{4}\left(\mathrm{AsO}_{4}\right)_{4}(\mathrm{OH})_{2} \cdot 4 \mathrm{H}_{2} \mathrm{O}\right.$; Roberts, Gault et al. (1997)], leisingite $\left[\mathrm{Cu}_{2} \mathrm{MgTe}^{\mathrm{VI}} \mathrm{O}_{6} \cdot 6 \mathrm{H}_{2} \mathrm{O}\right.$; Roberts et al.

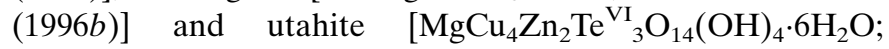
Roberts, Stirling et al. (1997b)]. The specimen from the Centennial Eureka Mine was used for $\mathrm{H}_{2} \mathrm{O}$ determination by Roberts et al. (1994). No crystal structure was reported for mcalpineite, although crystallization in a cubic space group with a primitive lattice (exact symmetry unknown) was reported. Roberts et al. (1994) also noted the similarity to synthetic $\mathrm{Cu}_{3}{ }_{3} \mathrm{Te}^{\mathrm{VI}} \mathrm{O}_{6}$, noting a $4 \AA$ void with 'marginally sufficient room' to incorporate an $\mathrm{H}_{2} \mathrm{O}$ molecule as indicated in the formula $\mathrm{Cu}_{3}{ }_{3} \mathrm{Te}^{\mathrm{VI}} \mathrm{O}_{6} \cdot \mathrm{H}_{2} \mathrm{O}$. A subsequent study on mcalpineite from the Gambatesa mine in Italy, along with a synthetic sample of $\mathrm{Cu}_{3}^{\mathrm{II}} \mathrm{Te}^{\mathrm{VI}} \mathrm{O}_{6}$ generated from binary oxides at high temperature, led to the redefinition of the species as anhydrous $\mathrm{Cu}_{3}{ }_{3} \mathrm{Te}^{\mathrm{VI}} \mathrm{O}_{6}$ (Carbone et al., 2013). Carbone et al. (2013) used powder X-ray diffraction, electron diffraction and Raman spectroscopic measurements to redefine mcalpineite in space group $I a \overline{3}$, i.e. as identical to synthetic $I$-centred $\mathrm{Cu}_{3}^{\mathrm{II}} \mathrm{Te}^{\mathrm{VI}} \mathrm{O}_{6}$. Carbone et al. (2013) concluded that the extra lines in the powder X-ray diffraction pattern of their natural mcalpineite sample [i.e. those contributing to the primitive unit cell described by Roberts et al. (1994)] were from an unidentified associated phase, rather than a $\mathrm{Cu}_{3}^{\mathrm{II}} \mathrm{Te}^{\mathrm{VI}} \mathrm{O}_{6}$ phase.

While generally rare, $\mathrm{Te}-\mathrm{O}$ minerals are a rich source of new and rare structures, increasingly solved through a combination of Rietveld refinement with a structural refinement due to the ever-decreasing crystal size of $\mathrm{Te}-\mathrm{O}$ minerals without a known structure (Nénert et al., 2020). While rare and polycrystalline, mcalpineite is now known to be far more common in Nature than when first discovered. It is prevalent at the Otto Mountain mines, California, where it forms early in the secondary mineral paragenetic sequence and is usually found as grass green coatings on rocks hosting suites of unique, rare secondary Te minerals (Housley et al., 2011; Christy et al., 2016a). Here, we present data on the structure and occurrence of the two polytypes of $\mathrm{Cu}_{3}{ }_{3}^{\mathrm{II}} \mathrm{Te}^{\mathrm{VI}} \mathrm{O}_{6}$, including assigning polytypes for well characterized mcalpineite occurrences.

\section{Experimental}

Descriptions of the syntheses of the $\mathrm{Cu}_{3}{ }_{3}^{\mathrm{II}} \mathrm{Te}^{\mathrm{VI}} \mathrm{O}_{6}$ polytypes and the provenance of the natural mcalpineite samples are summarized in the following two sections and in Table 1.

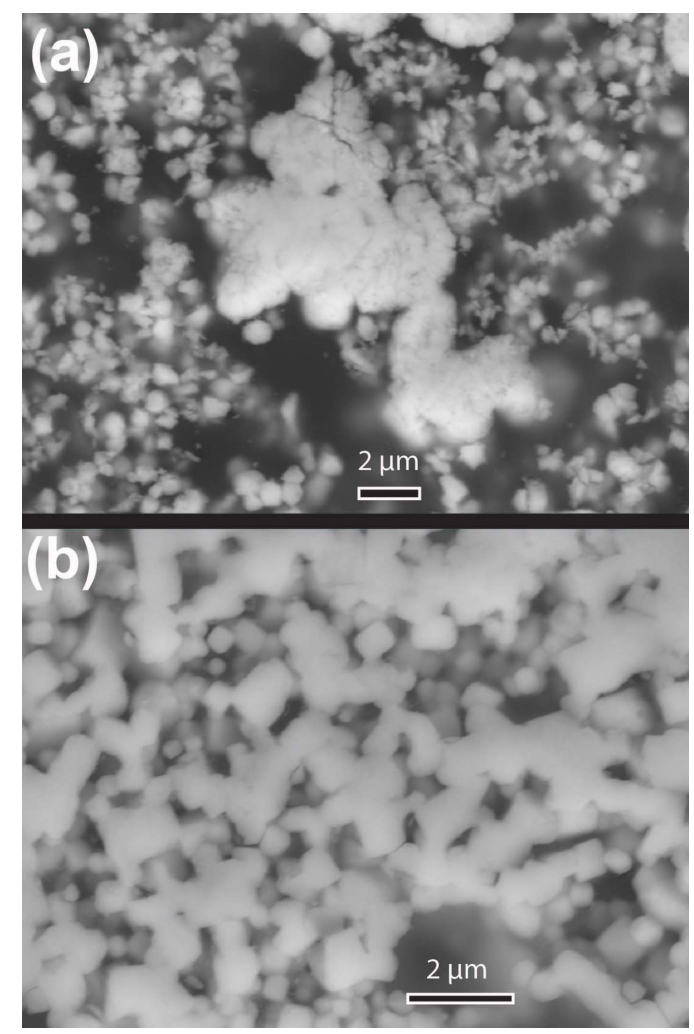

Figure 1

SEM images (backscatter electron mode) of synthetic $\mathrm{Cu}_{3}{ }_{3} \mathrm{Te}^{\mathrm{VI}} \mathrm{O}_{6}-2 O(a)$ and $\mathrm{Cu}_{3}{ }_{3} \mathrm{Te}^{\mathrm{VI}} \mathrm{O}_{6}-1 C$ from solid state synthesis $(b)$, showing $0.5 \mu \mathrm{m}$ prisms and $20 \mu \mathrm{m}$ polycrystalline aggregates of the $2 O$ polytype and $0.3-1.5 \mu \mathrm{m}$ cubes for the $1 C$ polytype. 
Table 1

Sample summary incorporating details of natural mcalpineite samples and synthetic $\mathrm{Cu}_{3}{ }_{3} \mathrm{Te}^{\mathrm{VI}} \mathrm{O}_{6}$ samples analysed in this study.

\begin{tabular}{|c|c|c|c|c|c|c|}
\hline Syn or nat & Polytype & Locality & Synthesis detail & XRPD & SEM or EPMA & IR or Raman \\
\hline Natural & $2 O$ & $\mathrm{BND}^{1}$ & NA & Yes & SEM & Raman \\
\hline Natural & $2 O$ & $\mathrm{Aga}^{2}$ & NA & Yes & SEM & Raman \\
\hline Natural & $2 O$ & Serita $^{3}$ & NA & Yes & Neither & Raman \\
\hline Natural & $2 O$ & $\mathrm{RM}^{5}$ & NA & Yes & Neither & Neither \\
\hline Natural & $2 O$ & Delamar $^{6}$ & NA & Yes & SEM & Raman \\
\hline Natural & $2 O$ & Wildcat $^{7}$ & NA & No & Neither & Raman \\
\hline Natural & $2 O$ & Norway $^{8}$ & NA & Yes & EPMA & Neither \\
\hline Synthetic & $1 C$ & NA & CVT & Yes & Neither & Both \\
\hline
\end{tabular}

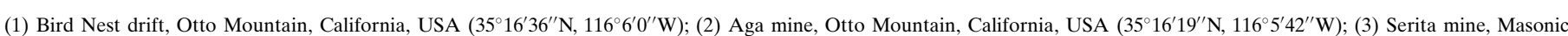

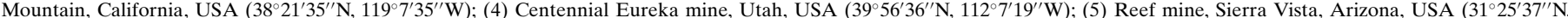

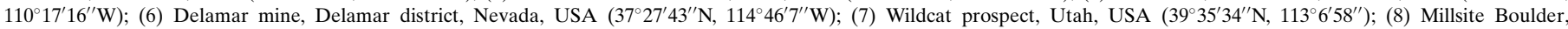
Gråurdfjellet, Norway $\left(62^{\circ} 29^{\prime} 11^{\prime \prime} \mathrm{N}, 9^{\circ} 29^{\prime} 25^{\prime \prime} \mathrm{E}\right)$, specimen number BM 2011,243 (Natural History Museum, London).

Table 2

Summary of synthetic $\mathrm{Cu}_{3}{ }_{3} \mathrm{Te}^{\mathrm{VI}} \mathrm{O}_{6}$ in literature studies.

\begin{tabular}{|c|c|c|c|c|c|c|c|}
\hline Reference & $\begin{array}{l}\text { Polytype } \\
\text { (if determinable) }\end{array}$ & Synthesis method & $\begin{array}{l}\text { Synthesis temperature } \\
\text { (K) }\end{array}$ & PD & SEM & $\begin{array}{l}\text { IR or } \\
\text { Raman }\end{array}$ & Study aim \\
\hline Herak et al. (2005) & $1 C$ & CVT & $723-773$ or $823-873$ & Yes, neutron & No & No & Magnetic properties \\
\hline Choi et al. (2008) & $1 C$ & CVT & Unstated & No & No & Raman & Magnetic properties \\
\hline Zhu et al. (2014) & $1 C$ & Sintering or calcination & 1138 or 1123 , respectively & Yes, X-ray & Yes & No & Ceramic dielectrics \\
\hline He \& Itoh (2014) & $1 C$ & Solid state & 1223 & Yes, X-ray & No & No & Magnetic properties \\
\hline Mutharani et al. (2020) & $1 C$ & Precipitation then calcination & Calcination at 873 & Yes, X-ray & Yes & No & Ibuprofen sensing \\
\hline
\end{tabular}

\subsection{Synthesis}

Three methods were employed for synthesis of $\mathrm{Cu}_{3}{ }_{3} \mathrm{Te}^{\mathrm{VI}} \mathrm{O}_{6}$ in this study: low-temperature hydrothermal synthesis, hightemperature solid-state synthesis and chemical vapour transport (CVT), the latter used to grow $\mathrm{Cu}_{3}^{\mathrm{II}} \mathrm{Te}^{\mathrm{VI}} \mathrm{O}_{6}$ crystals from material synthesized by the solid-state method. The archetypical synthetic samples used for most measurements are summarized in Table 1 and a summary of $\mathrm{Cu}_{3}{ }_{3} \mathrm{Te}^{\mathrm{VI}} \mathrm{O}_{6}$ syntheses in other studies is provided in Table 2. Scanning electron micrographs of the synthetic $\mathrm{Cu}_{3}^{\mathrm{II}} \mathrm{Te}^{\mathrm{VI}} \mathrm{O}_{6}$ polytypes were taken on a JEOL 7001 F FEG-SEM $(20 \mathrm{kV}, 3 \mathrm{nA}$ and $2 \mu \mathrm{m}$ beam diameter) at the Monash Centre for Electron Microscopy, Monash University, Australia (Fig. 1).

Hydrothermal synthesis of $\mathrm{Cu}_{3}{ }_{3} \mathrm{Te}^{\mathrm{VI}} \mathrm{O}_{6}$ was carried out in two batches of experiments. The first batch of experiments at Museums Victoria used the following $\mathrm{Cu}^{\mathrm{II}}$ compounds as starting materials: $\mathrm{CuO}, \mathrm{Cu}_{2}\left(\mathrm{CO}_{3}\right)(\mathrm{OH})_{2}$ and $\mathrm{Cu}\left(\mathrm{NO}_{3}\right)_{2} \cdot-$ $3 \mathrm{H}_{2} \mathrm{O}$, including $\mathrm{Cu}\left(\mathrm{NO}_{3}\right)_{2} \cdot 3 \mathrm{H}_{2} \mathrm{O}$ in combination with both other $\mathrm{Cu}^{\mathrm{II}}$ compounds. $\mathrm{Te}(\mathrm{OH})_{6}$ and $\mathrm{TeO}_{2}$ (the latter oxidized in situ) were used as the Te sources. The starting materials were added to $25 \mathrm{ml}$ Teflon-lined steel vessels, then filled to $10 \mathrm{ml}$ with water. These vessels were added to hand-tightened steel autoclaves and heated to $473 \mathrm{~K}$ for a period of 3-7 days, followed by furnace cooling. Hand-tightening allowed for more rapid evaporation of $\mathrm{H}_{2} \mathrm{O}$, and the products obtained were dry.

The second batch of experiments at TU Wien used $\mathrm{Cu}(\mathrm{OH})_{2}, \mathrm{Cu}\left(\mathrm{NO}_{3}\right)_{2} \cdot 2.5 \mathrm{H}_{2} \mathrm{O}, \mathrm{CuSO}_{4} \cdot 5 \mathrm{H}_{2} \mathrm{O}$ or $\mathrm{CuCl}_{2} \cdot 2 \mathrm{H}_{2} \mathrm{O}$ as $\mathrm{Cu}^{\mathrm{II}}$ sources. $\mathrm{Te}(\mathrm{OH})_{6}$ was most commonly used as the $\mathrm{Te}^{\mathrm{VI}}$ source, with $\mathrm{KTeO}(\mathrm{OH})_{5}$ used as an occasional alternative.
The reagents were added to Teflon-lined steel vessels (maximum capacity $7 \mathrm{ml}$ ) which were filled with water to an approximate two-thirds loading, then sealed in steel autoclaves via mechanical tightening and heated at autogenous pressure at $473 \mathrm{~K}$ for 2-11 days, followed by furnace cooling. The resultant contents of the Teflon vessels were filtered through a Büchner funnel, washing the solid products with mother liquor, then deionized water, ethanol and acetone, followed by drying in air. A 3:1 molar ratio of $\mathrm{Cu}^{\mathrm{II}}: \mathrm{Te}^{\mathrm{VI}}$ was

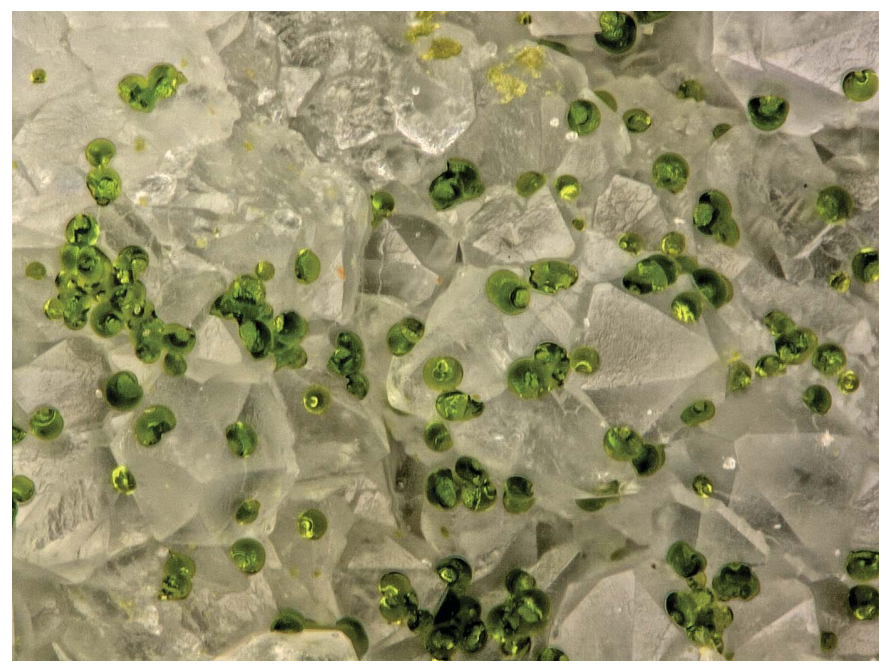

Figure 2

Natural mcalpineite- $2 O$ from Bird Nest drift, Otto Mountain as grassgreen spherules on quartz, FOV $0.56 \mathrm{~mm}$. Natural History Museum of Los Angeles County specimen number 69339. 
usually employed but other ratios were used on occasion when attempting to synthesize different $\mathrm{Cu}^{\mathrm{II}}-\mathrm{Te}^{\mathrm{VI}}$ minerals.

Solid-state synthesis of $\mathrm{Cu}_{3}{ }_{3} \mathrm{Te}^{\mathrm{VI}} \mathrm{O}_{6}$ employed a $\mathrm{Cu}^{\mathrm{II}}$ compound, either $\mathrm{Cu}(\mathrm{OH})_{2}$ or $\mathrm{Cu}\left(\mathrm{NO}_{3}\right)_{2} \cdot 2.5 \mathrm{H}_{2} \mathrm{O}$ with $\mathrm{Te}(\mathrm{OH})_{6}$, again in a 3:1 molar ratio. The reactants were weighed out and ground together in a mortar and pestle. Following initial heating to $673 \mathrm{~K}$ in a ceramic crucible over $2 \mathrm{~h}$, the reaction mixture (as black powder) was removed from the furnace and reground, then returned to the crucible and heated to the final reaction temperature of $873 \mathrm{~K}$ over the course of 1 hour. The crucible was maintained at $873 \mathrm{~K}$ for $24 \mathrm{~h}$ then cooled to room temperature over $5 \mathrm{~h}$, producing a grass-green powder.

CVT-based crystal growth (Binnewies et al., 2012) of $\mathrm{Cu}_{3}^{\mathrm{II}} \mathrm{Te}^{\mathrm{VI}} \mathrm{O}_{6}$ used previously solid-state synthesized $\mathrm{Cu}_{3}{ }_{3} \mathrm{Te}^{\mathrm{VI}} \mathrm{O}_{6}$ polycrystalline powders, with a 10:1 mass ratio of $\mathrm{Cu}_{3}{ }_{3} \mathrm{Te}^{\mathrm{VI}} \mathrm{O}_{6}$ with the $\mathrm{Cl}_{2}$ source, $\mathrm{PtCl}_{2}$. The reagents (overall load $c a 0.2 \mathrm{~g}$ ) were ground together with a mortar and pestle, then vacuum-sealed in a silica glass ampoule and placed in a temperature gradient furnace for a period of two weeks. The temperature was set at $1023 \mathrm{~K}$ at the source end and $953 \mathrm{~K}$ at the sink end. Amorphous green material was produced on top of bubbled glass, indicating attack of the glass surface by the reagents. Dark-green, well faceted octahedral crystals of $\mathrm{Cu}_{3}^{\mathrm{II}} \mathrm{Te}^{\mathrm{VI}} \mathrm{O}_{6}$ were grown in the sink end of the glass ampoule, with no other crystalline phases detected.

\subsection{Sample details}

Natural mcalpineite samples from seven localities were analysed, with summary details shown in Table 1 . In almost all cases, mcalpineite forms grass-green coatings, occasionally botryoidal in nature, on quartz (Fig. 2) or as polycrystalline crusts. Well formed single crystals of mcalpineite (micronscale dimensions) are so far not known in Nature. Mcalpineite from the Millsite Boulder, Gråurdfjellet, Norway $\left(62^{\circ} 29^{\prime} 11^{\prime \prime} \mathrm{N}\right.$, $9^{\circ} 29^{\prime} 25^{\prime \prime} \mathrm{E}$; Rumsey et al., 2018) forms a botryoidal dark-olivegreen to black crust with no visible crystallinity. Despite the darker visual appearance, the streak is bright green, typical of mcalpineite.

\subsection{D electron diffraction}

Three-dimensional electron diffraction (3D ED) series from a $10 \times 15 \times 20 \mathrm{~nm}$ single crystal were acquired on a FEI Titan 'cubed' microscope operated at $300 \mathrm{kV}$. 3D ED is becoming a more prominent tool in inorganic chemistry as it allows for the analysis of nanocrystals (Kolb et al., 2007; Gemmi et al., 2019).

The sample was prepared for the analysis by manually grinding the powder in an agate mortar, recovering the resulting powder with ethanol, and sonicating the resulting suspension for $10 \mathrm{~min}$ at room temperature. The thus-obtained suspension was appropriately diluted with ethanol and used to deposit one droplet on a copper grid for TEM analysis. The sample grid was loaded on a Fischione2020 tomography holder, and inserted in the TEM column at room temperature without further treatment. The electron beam was adjusted using spot size No. 9 ( $\sim 190 \mathrm{~nm}$ beam size at the sample), and condenser apertures $\mathrm{C} 1, \mathrm{C} 2$, and $\mathrm{C} 3$ of $2000 \mu \mathrm{m}, 50 \mu \mathrm{m}$ and $2000 \mu \mathrm{m}$, respectively, while a selected aperture was used to selectively illuminate the sample during data acquisition. Static ED patterns were collected every $0.5^{\circ}$, covering a range of $140^{\circ}$ by using custom-made script for Digital Micrograph for stepwise ED data acquisition, while the camera length was set at $285 \mathrm{~mm}$. Data integration was conducted by using the software PETS2.0 using an integration range of $0.25-1.25 \AA^{-1}$ (Palatinus et al., 2019), while for structure solution and refinement by the charge-flipping method, the programs Superflip (Palatinus \& Chapuis, 2007) and Refine (leastsquares) were used within the software Jana2020 (Petrríček et al., 2014). Note that the low number of reflections used for indexing is due to the presence of a minor twin domain in the data. This did not create noteworthy problems in the indexing and refinement of the unit-cell, nor did it affect the reciprocal space reconstructions. However, to avoid the presence of this parasitic domain in the peak table used for unit-cell determination, we used an intensity threshold that filtered out the weakest reflections, thus effectively decreasing their number compared to the total number of observed reflections.

The crystal structure refined by 3D ED data can be accessed free of charge from the joint CCDC and FIZ Karlsruhe's access service WebCSD (https://www.ccdc.cam.ac.uk/structures/) by entering the reference code CSD2110654.

\subsection{X-ray powder diffraction}

2.4.1. Fingerprint scans. Fingerprint $X$-ray powder diffraction (XRPD) scans were performed on a Philips X'Pert diffractometer, Museums Victoria, Australia, using $\mathrm{Cu} K \alpha$ radiation $(40 \mathrm{kV}$ and $40 \mathrm{~mA})$ for the pilot-project hydrothermal syntheses. All subsequent $\mathrm{Cu}_{3}{ }_{3} \mathrm{Te}^{\mathrm{VI}} \mathrm{O}_{6}$ samples were synthesized at TU Wien, in which case representative samples of the bulk products were ground, fixed with small amounts of petroleum jelly on zero-background silicon wafers and measured with $\mathrm{Cu} K \alpha_{1,2}$ radiation in Bragg-Brentano geometry on a PANalytical X'PertPro system. Example XRPD scans of synthetic $\mathrm{Cu}_{3}{ }_{3} \mathrm{Te}^{\mathrm{VI}} \mathrm{O}_{6}-1 C$ and $\mathrm{Cu}_{3}{ }_{3} \mathrm{Te}^{\mathrm{VI}} \mathrm{O}_{6}-2 O$ are shown in Fig. 3.

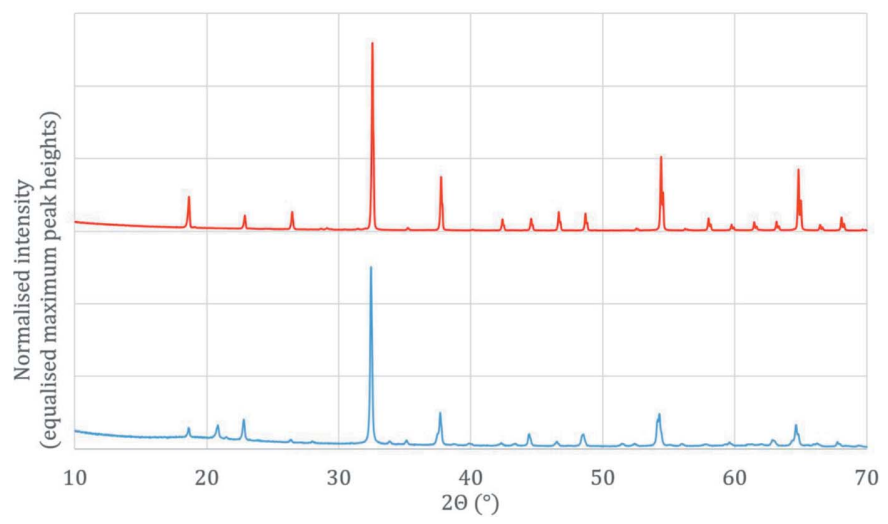

Figure 3

Representative XRPD scans collected using $\mathrm{Cu} K \alpha$ of both $\mathrm{Cu}_{3}{ }_{3}^{\mathrm{II}} \mathrm{Te}^{\mathrm{VI}} \mathrm{O}_{6^{-}}$ $1 C$ (above, red) and $\mathrm{Cu}_{3}{ }_{3} \mathrm{Te}^{\mathrm{VI}} \mathrm{O}_{6}-2 O$ (below, blue) polytypes of synthetic $\mathrm{Cu}_{3}^{\mathrm{II}} \mathrm{Te}^{\mathrm{VI}} \mathrm{O}_{6}$. Scans normalized to the height of the maximum peak. 
Table 3

ED and Rietveld structural refinement details of $\mathrm{Cu}_{3}{ }_{3} \mathrm{Te}^{\mathrm{VI}} \mathrm{O}_{6}-2 O$.

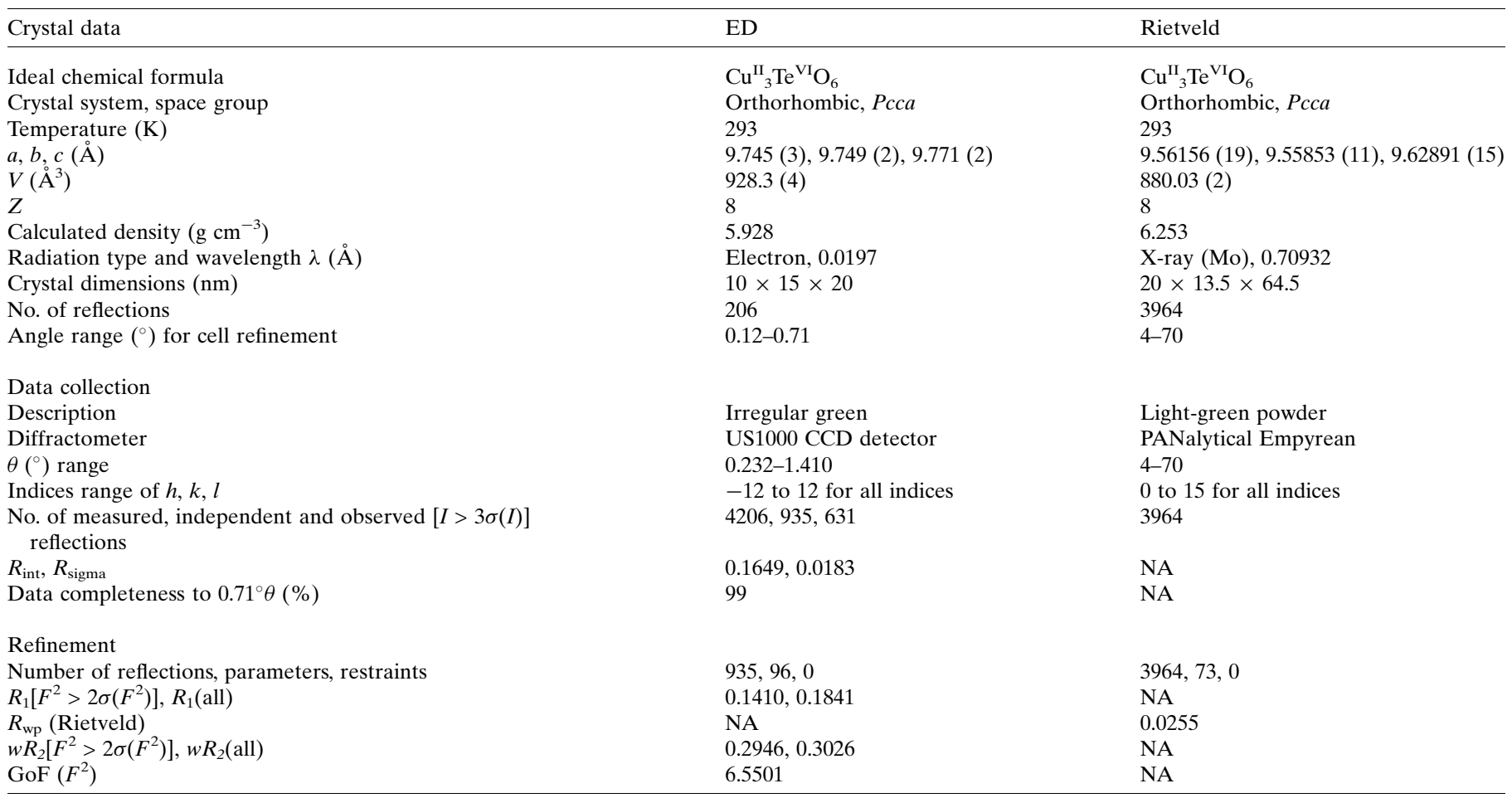

The majority of XRPD scans on natural samples were collected on a Rigaku R-Axis Rapid II curved imaging plate diffractometer using Mo $K \alpha$ radiation at the Natural History Museum of Los Angeles County and a dataset collected using Mo $K \alpha$ radiation to $32^{\circ} 2 \theta$. The only exception was the XRPD scan for the Norway sample, collected on a Rigaku R-Axis Rapid II diffractometer at the Natural History Museum, London, with a dataset collected using $\mathrm{Cu} K \alpha$ radiation to $80^{\circ} / 2 \theta$.

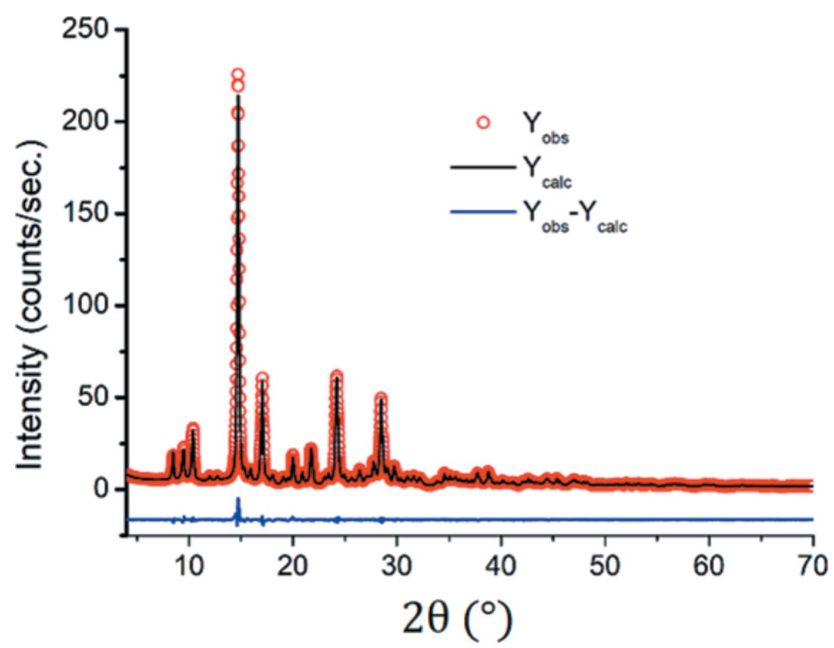

Figure 4

Rietveld refinement of $\mathrm{Cu}_{3}{ }_{3} \mathrm{Te}^{\mathrm{VI}} \mathrm{O}_{6}-2 O$ collected with Mo radiation $\left(R_{\mathrm{wp}}\right.$ $=2.55 \%$ ).
2.4.2. Rietveld refinement. For high-resolution Rietveld refinement, a XRPD scan of synthetic $\mathrm{Cu}_{3}{ }_{3} \mathrm{Te}^{\mathrm{VI}} \mathrm{O}_{6}-2 O$ was undertaken (Fig. 4). To ensure a totally random orientation for XRPD analysis, the sample powder was loaded into borosilicate glass capillary tubes (external diameter $0.5 \mathrm{~mm}$, wall thickness $0.01 \mathrm{~mm}$ ). XRD analysis was carried out at room temperature using a PANalytical Empyrean diffractometer with a Debye-Scherrer geometry. For optimal data collection, hard radiation was used (high-resolution Mo tube) with an incident beam focusing mirror and a GalPIX ${ }^{3 \mathrm{D}}$ detector. The capillary was rotated at a speed of 5 revolutions/s and scans performed in the range $2 \theta=4-70^{\circ}$ with a step size of $0.014^{\circ}$. A variable counting time strategy was employed to increase the counting statistics (refinement details shown in Table 3).

2.4.3. In situ XRPD. In situ XRPD scans were performed under atmospheric conditions on a HTK1200 Anton-Paar high-temperature oven chamber using a Philips X'Pert diffractometer at TU Wien. The sample used was hydrothermally synthesized $\mathrm{Cu}_{3}{ }_{3} \mathrm{Te}^{\mathrm{VI}} \mathrm{O}_{6}-2 O$. The sample was loaded into a corundum sample holder and held at $298 \mathrm{~K}$ for 10 minutes then at $348 \mathrm{~K}$ for $2.5 \mathrm{~h}$ to drive off any remaining moisture. Heating was performed at a rate of $60 \mathrm{~K} \mathrm{~h}^{-1}$, with a powder diffraction scan recorded every $5 \mathrm{~K}$. The temperature remained constant during the scan time. Scans were recorded from $298 \mathrm{~K}$ to $873 \mathrm{~K}$, with an additional scan collected following cooling back to $303 \mathrm{~K}$.

2.4.4. Raman spectroscopy. Raman spectra on synthetic samples (Fig. 5) were collected at Universität Wien on a Renishaw RM1000 confocal edge filter-based micro-Raman system. The $488 \mathrm{~nm}$ excitation line of a $\sim 20 \mathrm{~mW}$ Ar-ion laser 
was focused with a $50 \times / 0.75$ objective lens on the sample surface. The back-scattered radiation $\left(180^{\circ}\right.$ configuration) was analysed with a 1200 lines $/ \mathrm{mm}$ grating monochromator. Raman intensities were collected for $30 \mathrm{~s}$ (spectral range 4000 to $\sim 70 \mathrm{~cm}^{-1}$ in continuous grating scan mode) with a thermoelectrically cooled CCD array detector. The spectral resolution of the system was $5-6 \mathrm{~cm}^{-1}$, the wavenumber accuracy was $1 \mathrm{~cm}^{-1}$ (both calibrated with the Rayleigh line and the $521 \mathrm{~cm}^{-1}$ line of a $\mathrm{Si}$ standard). The confocal setup limited the spatial (lateral and depth) resolution to $2-3 \mu \mathrm{m}$. Instrument control and data acquisition were done with Grams/32 software (Galactic Ind. Corp.). Raman spectra on CVT-produced $\mathrm{Cu}_{3}{ }_{3}^{\mathrm{II}} \mathrm{Te}^{\mathrm{VI}} \mathrm{O}_{6}$ were collected for $120 \mathrm{~s}$ using full laser power. Hydrothermally produced $\mathrm{Cu}_{3}^{\mathrm{II}}{ }_{3} \mathrm{Te}^{\mathrm{VI}} \mathrm{O}_{6}$ was visibly burnt at full laser power, hence spectra were collected for $120 \mathrm{~s}$ with laser power attenuated to $10 \%$. No features were observed between 4000 and $1100 \mathrm{~cm}^{-1}$ for either specimen.

Raman spectra on two mcalpineite specimens from Bird Nest drift at Otto Mountain were collected at Caltech, also on

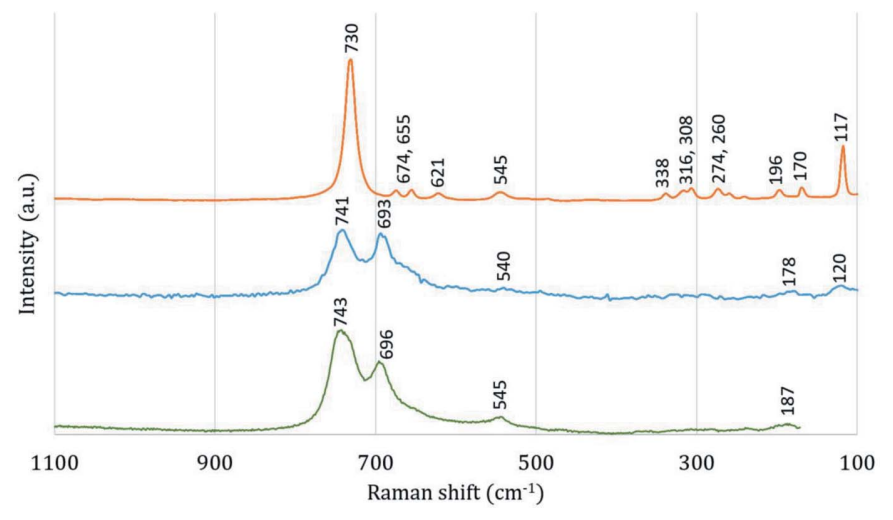

Figure 5

Representative Raman spectra of the synthetic $\mathrm{Cu}_{3}{ }_{3} \mathrm{Te}^{\mathrm{VI}} \mathrm{O}_{6}-1 C$ polytype synthesized by CVT (orange), synthetic hydrothermal $\mathrm{Cu}_{3}{ }_{3} \mathrm{Te}^{\mathrm{VI}} \mathrm{O}_{6}-2 O$ polytype (blue) and a natural sample from Bird Nest drift, Otto Mountain, California (green - note that a different instrument was used, with a $170 \mathrm{~cm}^{-1}$ cut-off) with key vibration lines labelled.

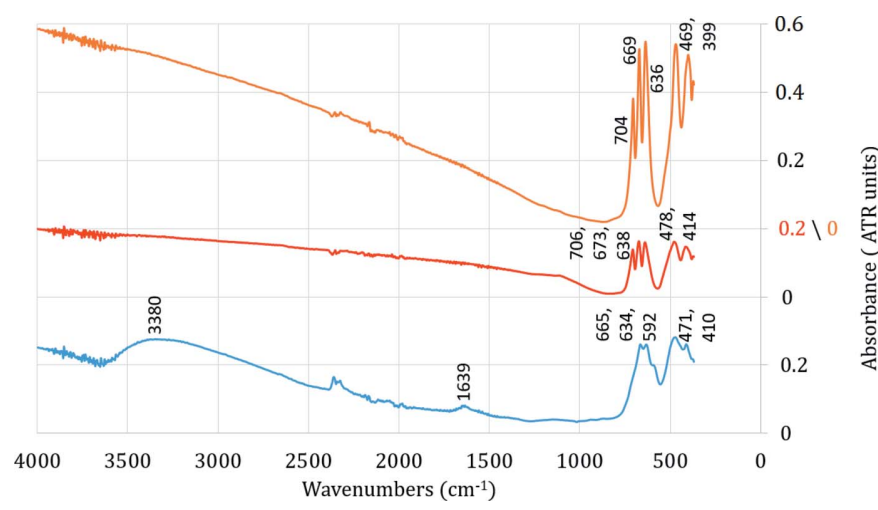

Figure 6

Representative IR spectra of the $\mathrm{Cu}^{\mathrm{II}}{ }_{3} \mathrm{Te}^{\mathrm{VI}} \mathrm{O}_{6}-1 C$ synthesized by CVT (orange), synthetic $\mathrm{Cu}_{3}^{\mathrm{II}} \mathrm{Te}^{\mathrm{VI}} \mathrm{O}_{6}-1 C$ synthesized by solid-state reaction (red) and hydrothermal $\mathrm{Cu}_{3}{ }_{3} \mathrm{Te}^{\mathrm{VI}} \mathrm{O}_{6}-2 O$ (blue) key vibration lines labelled. a Renishaw RM1000 spectrometer but this time with a $514 \mathrm{~nm}$ solid-state laser (Fig. 5). Most scanning was done at $10 \%$ power and $20 \times$ magnification resulting in a $5 \mu \mathrm{m}$ spot size, collecting a spectral range of 1600 to $\sim 170 \mathrm{~cm}^{-1}$ in continuous grating scan mode. A polarization scrambler was used to minimize polarization effects and the energy scale was also calibrated with silicon. Other details are as above for the synthetic samples.

\subsection{IR spectroscopy}

IR spectra of the two polytypes (Fig. 6) were collected from 4000 to $370 \mathrm{~cm}^{-1}$ on a Bruker TENSOR 27 Fourier-transform infrared (FTIR) spectrometer equipped with a HARRICK MVP2 diamond attenuated total reflectance (ATR) unit at Universität Wien. A glowbar lightsource, a $\mathrm{KBr}$ beam splitter, and a DLaTGS detector were used. Each 32 spectra, with a resolution of $4 \mathrm{~cm}^{-1}$, were averaged for a good signal-to-noise ratio both for reference (from the empty ATR unit) and sample spectra. Instrument control and data handling was done with Bruker OPUS 5.5 software.

\subsection{Thermal analysis}

Differential scanning calorimetry (DSC) measurements were performed under flowing argon atmosphere $\left(10 \mathrm{ml} \mathrm{min}{ }^{-1}\right)$ on a Netzsch DSC $200 \mathrm{~F} 3$ at TU Wien, using a $\sim 10 \mathrm{mg}$ dried sample of powdered, synthetic $\mathrm{Cu}_{3}^{\mathrm{II}} \mathrm{Te}^{\mathrm{VI}} \mathrm{O}_{6}-2 O$.

Thermogravimetric analysis (TGA) measurements were performed under flowing argon atmosphere $\left(10 \mathrm{ml} \mathrm{min}^{-1}\right)$ on a Netzsch TG 209 T3 at TU Wien, again using a $\sim 10 \mathrm{mg}$ dried sample of powdered, synthetic $\mathrm{Cu}_{3}{ }_{3} \mathrm{Te}^{\mathrm{VI}} \mathrm{O}_{6}-2 O$.

\subsection{Electron probe micro-analysis}

Quantitative chemical analyses of mcalpineite, sample BM 2011,243 from Millsite Boulder, Gråurdfjellet, Norway, were performed on a Cameca SX100 Electron Microprobe (WDS mode, $12 \mathrm{kV}, 10 \mathrm{nA}, 5 \mu \mathrm{m}$ beam diameter and PAP matrix correction) at the Imaging and Analysis Centre, Core Research Laboratories, Natural History Museum, London. $\mathrm{Fe}_{2} \mathrm{O}_{3}, \mathrm{CuO}, \mathrm{TeO}_{3}$ and $\mathrm{UO}_{2}$ were analysed, with $\mathrm{Fe}_{2} \mathrm{O}_{3}$ totals not exceeding $0.1 \mathrm{wt} \%$. $\mathrm{CaO}$ and $\mathrm{As}_{2} \mathrm{O}_{5}$ were also sought, but not detected. No other elements were detected using energy dispersive X-ray spectroscopy or electron probe microanalysis (EPMA) and as a known anhydrous mineral there was no need to calculate $\mathrm{H}_{2} \mathrm{O}$.

\section{Results and discussion}

\subsection{Crystal structure of the polytypes}

3.1.1. $\mathrm{Cu}_{3}{ }_{3} \mathrm{Te}^{\mathrm{VI}} \mathrm{O}_{6}-1 C$. $\mathrm{Cu}_{3}{ }_{3} \mathrm{Te}^{\mathrm{VI}} \mathrm{O}_{6}-1 C$ has a bixbyite-like structure (Fig. 7) consisting of $\mathrm{Cu}^{\mathrm{II}} \mathrm{O}_{6}$ and $\mathrm{Te}^{\mathrm{VI}} \mathrm{O}_{6}$ octahedra as revealed by one previous single-crystal X-ray diffraction study (Falck et al., 1978) and two Rietveld refinements (Hostachy \& Coing-Boyat, 1968; Carbone et al., 2013). $\mathrm{Cu}_{3}^{\mathrm{II}} \mathrm{Te}^{\mathrm{VI}} \mathrm{O}_{6}-1 C$ (space group $I a \overline{3}$ ), has only three distinct sites: one $\mathrm{Cu}$ (multiplicity 24, Wyckoff letter $d$, site symmetry 2..), one Te 
$(8 b, \overline{3}$. $)$, and one $\mathrm{O}(48 e, 1)$ site. The $\mathrm{Cu}^{\mathrm{II}} \mathrm{O}_{6}$ octahedra form a three-dimensional framework via both edge- and cornersharing. $\mathrm{Cu}-\mathrm{O}$ bond lengths are $2 \times 1.949$ (2) $\AA$ and $2 \times$ 2.031 (3) $\AA$ for equatorial bond lengths and $2 \times 2.369$ (3) $\AA$ for axial bond lengths (Falck et al., 1978). These $\mathrm{Cu}^{\mathrm{II}} \mathrm{O}_{6}$ octahedra are asymmetric as well as Jahn-Teller distorted, with a $\mathrm{O}_{\text {axial }}-\mathrm{Cu}-\mathrm{O}_{\text {axial }}$ angle of $\sim 133^{\circ}$, while $\mathrm{Te}^{\mathrm{VI}} \mathrm{O}_{6}$ octahedra are symmetrical with six $\mathrm{Te}-\mathrm{O}$ bonds at 1.921 (2) $\AA$. The $\mathrm{Te}^{\mathrm{VI}} \mathrm{O}_{6}$ octahedra are isolated from each other and are linked into the $\{\mathrm{Cu}-\mathrm{O}\}$ framework via edge-sharing with $\mathrm{Cu}^{\mathrm{II}} \mathrm{O}_{6}$ octahedra (Christy et al., 2016b). The remaining void space in the structure is not large enough to incorporate $\mathrm{H}_{2} \mathrm{O}$ molecule without significant rearrangement of the framework (Carbone et al., 2013).

3.1.2. $\mathrm{Cu}^{\mathrm{II}}{ }_{3} \mathrm{Te}^{\mathrm{VI}} \mathrm{O}_{6}-2 \mathrm{O}$. The crystal structure of $\mathrm{Cu}_{3}^{\mathrm{II}} \mathrm{Te}^{\mathrm{VI}} \mathrm{O}_{6}-2 \mathrm{O}$ has been first determined during the current study by $3 \mathrm{D}$ ED. The Pcca space group was assigned upon observation, in reciprocal space reconstructions of the main zones, of the corresponding extinction rules $[l=2 n$ in $(0 k l)$ and

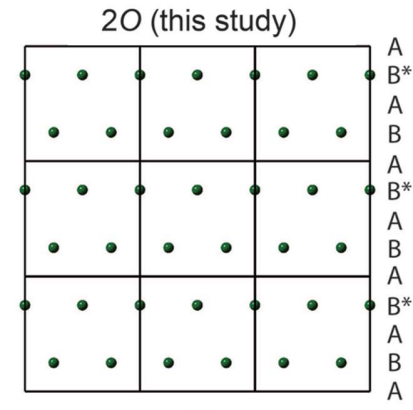

(a)

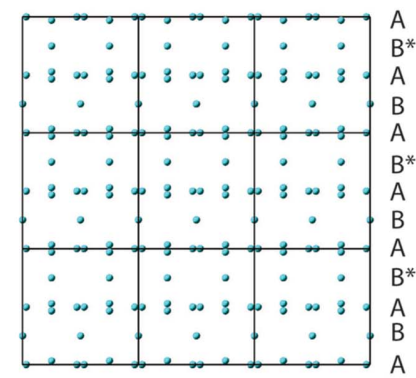

(c)

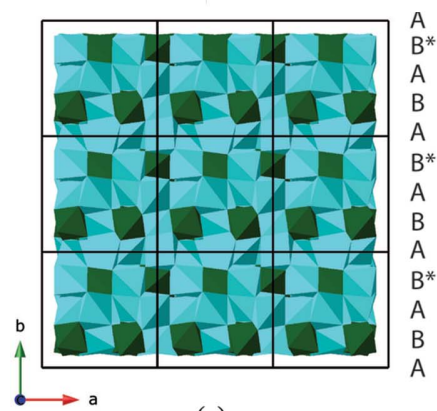

(e)

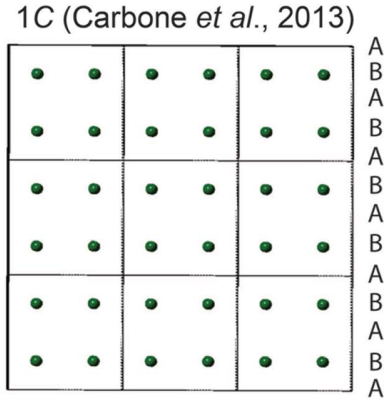

(b)

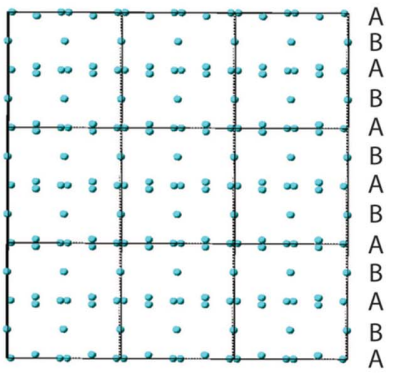

(d)

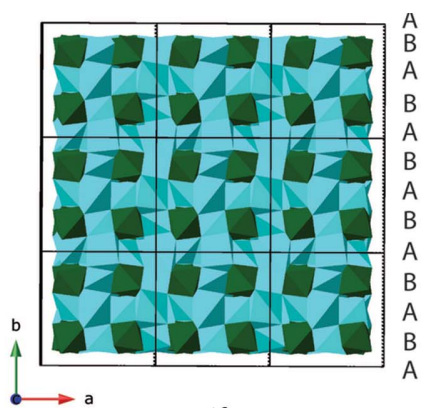

$(f)$
Figure 7

Crystal structure comparison of $\mathrm{Cu}_{3}{ }_{3}^{\mathrm{II}} \mathrm{Te}^{\mathrm{VI}} \mathrm{O}_{6}-2 O$ and $\mathrm{Cu}_{3}{ }_{3}^{\mathrm{II}} \mathrm{Te}^{\mathrm{VI}} \mathrm{O}_{6}-1 C$ comparing Te sites $(a$ and $b), \mathrm{Cu}(c$ and $d)$ and overall octahedral stacking $(e$ and $f)$. Te shown in dark green and $\mathrm{Cu}$ in light blue, drawn using Crystalmaker (Palmer, 2009). $(h 0 l), h=2 n$ in $(h k 0)$; Fig. 8]. After structure solution and refinement, the final structure was checked for compatible higher space-group symmetry by the ADDSYM tool of the program PLATON (Spek, 2020), which did not find any suitable alternative setting. $\mathrm{Cu}_{3}{ }_{3} \mathrm{Te}^{\mathrm{VI}} \mathrm{O}_{6}-2 O$ contains the same octahedral building blocks as $\mathrm{Cu}_{3}{ }_{3} \mathrm{Te}^{\mathrm{VI}} \mathrm{O}_{6}-1 C$, however the octahedral layers contain a different stacking arrangement (Fig. 7). The lower symmetry of the $2 \mathrm{O}$ polytype is generated by the movement of every second $\mathrm{Cu}^{\mathrm{II}} \mathrm{O}_{6}$ and $\mathrm{Te}^{\mathrm{VI}} \mathrm{O}_{6}$ octahedral layer by $(1 / 4,1 / 4,0)$, leading to an offset of $\mathrm{Te}^{\mathrm{VI}} \mathrm{O}_{6}$ and
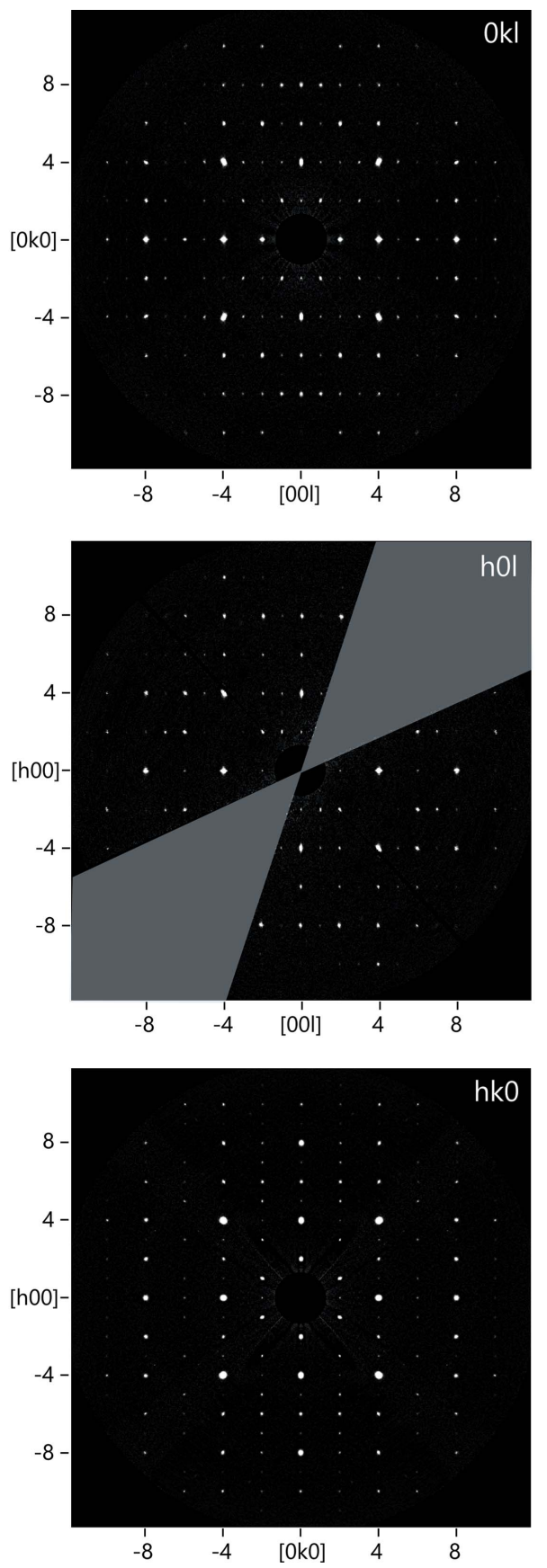

Figure 8

Reconstructed main zones from the $3 \mathrm{D}$ ED analysis of $\mathrm{Cu}_{3}{ }_{3} \mathrm{Te}^{\mathrm{VI}} \mathrm{O}_{6}-2 O$; the missing fraction of reciprocal space is highlighted in grey. 
$\mathrm{Cu}^{\mathrm{II}} \mathrm{O}_{6}$ octahedra in every second layer giving an $A B A B^{*}$ stacking arrangement.

As a result of the lower symmetry, a larger number of unique crystallographic sites are present in the crystal structure of $\mathrm{Cu}_{3}{ }_{3} \mathrm{Te}^{\mathrm{VI}} \mathrm{O}_{6}-2 O$, namely five $\mathrm{Cu}(4 a, 1 ; 4 c, .2 . ; 4 e, . .2 ; 4 e$, $. .2 ; 4 c, .2$.), two Te $(4 b, 1 ; 4 d, . .2)$ and six $\mathrm{O}$ sites (all on $8 f, 1)$ (Fig. 9). A greater range of bond lengths compared to the $1 C$ polytype is also observed to accommodate the stacking offset, with up to $0.13 \AA$ of variation observed for $\mathrm{Cu}-\mathrm{O}$ bonds and up to a $0.18 \AA$ increase in bond length for $\mathrm{Te}-\mathrm{O}$ bonds observed in the 3D ED refinement. The average $\mathrm{Cu}-\mathrm{O}$ equatorial bond length in $\mathrm{Cu}_{3}{ }_{3}^{\mathrm{II}} \mathrm{Te}^{\mathrm{VI}} \mathrm{O}_{6}-2 O$ is $2.025 \AA$ and the $\mathrm{Cu}-\mathrm{O}$ axial bond length is $2.425 \AA$. The $\mathrm{Te} 1 \mathrm{O}_{6}$ octahedron is close to symmetrical (Mills \& Christy, 2013), with all bonds between 1.969 (14) $\AA$ and 1.988 (15) $\AA$, whereas the $\mathrm{Te}^{2} \mathrm{O}_{6}$ octahedron is more distorted, with $2 \times \mathrm{Te} 2-\mathrm{O} 6$ bonds at

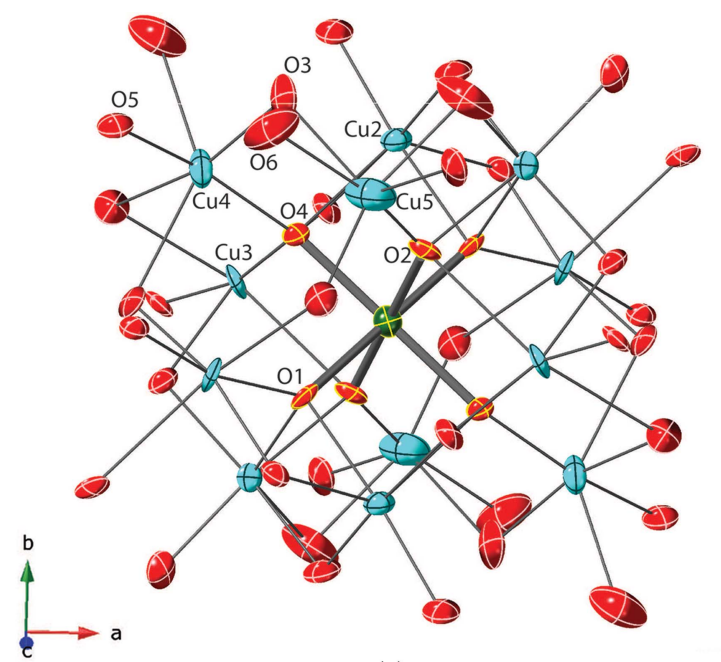

(a)

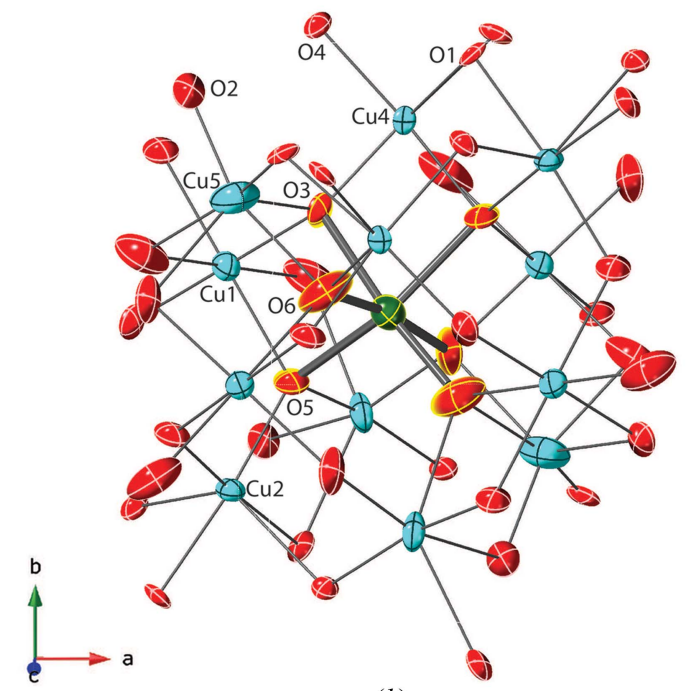

(b)

Figure 9

Crystal structure of $\mathrm{Cu}_{3}{ }_{3} \mathrm{Te}^{\mathrm{VI}} \mathrm{O}_{6}-2 O$ showing local bonding environments around $(a) \mathrm{Te} 1$ and $(b) \mathrm{Te} 2$. Colour scheme as above with $\mathrm{O}$ atoms in red, with the six $\mathrm{Te}-\mathrm{O}$ bonds shown as thick cylinders and these $\mathrm{O}$ atoms in yellow highlight. Ellipsoids shown at the $50 \%$ probability level, drawn using Crystalmaker (Palmer, 2009).
Table 4

Atomic coordinates and displacement parameters for $\mathrm{Cu}_{3}^{\mathrm{II}} \mathrm{Te}^{\mathrm{VI}} \mathrm{O}_{6}-2 O$ refined from 3D ED (regular text) and Rietveld (italic, shown for refined values) refinement.

\begin{tabular}{lllll}
\hline Atom & $x / a$ & $y / b$ & $z / c$ & $U_{\text {eq }}$ \\
\hline Cu1 & $\frac{1}{2}$ & 1 & $\frac{1}{2}$ & $0.0239(14)$ \\
& & & & $0.01011(19)$ \\
Cu2 & $\frac{1}{2}$ & $0.7169(8)$ & $\frac{1}{4}$ & $0.0356(18)$ \\
& & $0.7205(5)$ & & $0.01011(19)$ \\
Cu3 & $\frac{3}{4}$ & $\frac{1}{2}$ & $0.2166(9)$ & $0.028(2)$ \\
& & & $0.2180(3)$ & $0.01011(19)$ \\
$\mathrm{Cu} 4$ & $0.2191(5)$ & $0.7482(6)$ & $0.5046(10)$ & $0.020(2)$ \\
& $0.2157(3)$ & $0.7484(4)$ & $0.4998(3)$ & $0.01011(19)$ \\
$\mathrm{Cu} 5$ & $\frac{1}{2}$ & $0.2208(11)$ & $\frac{1}{4}$ & $0.021(2)$ \\
& & $0.2244(5)$ & & $0.01011(19)$ \\
Te1 & $\frac{1}{2}$ & $\frac{1}{2}$ & $\frac{1}{2}$ & $0.0355(17)$ \\
& & & & $0.0112(8)$ \\
Te2 & $\frac{3}{4}$ & 0 & $0.3028(6)$ & $0.044(4)$ \\
& & & $0.30388(17)$ & $0.0159(8)$ \\
O1 & $0.6189(14)$ & $0.5762(14)$ & $0.3532(17)$ & $0.022(4)$ \\
& $0.6176(14)$ & $0.5795(15)$ & $0.3482(12)$ & $0.01011(19)$ \\
O2 & $0.4304(16)$ & $0.3500(15)$ & $0.3824(19)$ & $0.030(5)$ \\
& $0.4254(16)$ & $0.3544(11)$ & $0.3857(15)$ & $0.01011(19)$ \\
O3 & $0.3546(16)$ & $0.8778(18)$ & $0.5641(18)$ & $0.034(6)$ \\
& $0.3623(13)$ & $0.8642(12)$ & $0.5666(15)$ & $0.01011(19)$ \\
O4 & $0.3555(15)$ & $0.6174(14)$ & $0.4220(17)$ & $0.023(5)$ \\
& 0.33984 & $0.6067(11)$ & $0.4283(14)$ & $0.01011(19)$ \\
O5 & $0.4000(17)$ & $0.8580(15)$ & $0.140(2)$ & $0.033(6)$ \\
& $0.3965(15)$ & 0.85823 & $0.1547(11)$ & $0.01011(19)$ \\
O6 & $0.643(2)$ & $0.091(2)$ & $0.169(2)$ & $0.055(8)$ \\
& $0.6298(14)$ & $0.0906(13)$ & $0.1614(12)$ & $0.01011(19)$ \\
\hline & & & &
\end{tabular}

$1.90(2) \AA, 2 \times \mathrm{Te} 2-\mathrm{O} 3$ bonds at 2.037 (18) $\AA$ and $2 \times$ $\mathrm{Te} 2-\mathrm{O} 5$ bonds at 2.089 (16) $\AA$ (Fig. 9). Te1O 6 octahedra and $\mathrm{Cu} 2 \mathrm{O}_{6}$ octahedra are found in one $\{\mathrm{Cu}-\mathrm{Te}-\mathrm{O}\}$ layer and $\mathrm{Te}_{2} \mathrm{O}_{6}$ octahedra and $\mathrm{Cu} 3 \mathrm{O}_{6}$ octahedra in the other. The remaining three $\mathrm{CuO}_{6}$ octahedra $(\mathrm{Cu} 1, \mathrm{Cu} 4$ and $\mathrm{Cu} 5)$ are found in the alternating $\{\mathrm{Cu}-\mathrm{O}\}$ layers.

\subsection{Rietveld refinement of $\mathrm{Cu}_{3}{ }_{3} \mathrm{Te}^{\mathrm{VI}} \mathrm{O}_{6}-2 \mathrm{O}$}

The unit-cell parameters of $\mathrm{Cu}_{3}{ }_{3} \mathrm{Te}^{\mathrm{VI}} \mathrm{O}_{6}-2 O$ from the Rietveld refinement $[a=9.56157$ (19) $\AA, b=9.55853$ (11) $\AA$ and $c=9.62891(15) \AA]$ are $\sim 1.5 \%$ lower than those determined by $3 \mathrm{D}$ ED, well within the $3 \%$ error typically assumed for 3D ED measurements of this nature. The experimental powder pattern presents an anisotropic peak shape which results from anisotropic crystallite size, which was treated using spherical harmonics. To be able to estimate the average crystallite size and shape, the instrumental contribution was evaluated using a silicon reference sample. The average crystallite topology can be represented by a elongated platelike shape formed from two smaller fused crystallites, with estimated dimensions $20 \times 13.5 \times 64.5 \mathrm{~nm}$ along the main crystallographic directions (Fig. 10).

The structure derived from the Rietveld refinement is similar to that determined from 3D ED, with the most notable difference observed for the $\mathrm{Cu} 1$ site. In the 3D ED refinement, the two Cu1-O5 bonds are equatorial 2.177 (17) $\AA$ and Cu1-O6 bonds are axial 2.34 (2) $\AA$, whereas in the Rietveld refinement the $\mathrm{Cu} 1-\mathrm{O} 6$ bonds are shorter than the $\mathrm{Cu} 1-\mathrm{O} 5$ bonds, 2.169 (13) and 2.244 (10) $\AA$ respectively. The smaller 
unit-cell in the Rietveld refinement also leads to shorter $\mathrm{Cu}-\mathrm{O}$ bonds on average compared to the 3D ED refinement, with an average $1.977 \AA$ axial bond length and $2.380 \AA$ equatorial bond length, compared to 2.025 and $2.425 \AA$ for the 3D ED refinement, respectively. This leads to higher bondvalence sums for the $\mathrm{Cu}^{\mathrm{II}}$ sites, 2.10 compared to 1.83 valence units. Despite these bond-length differences, the topology of the structures as determined from the two techniques is near identical (see comparisons in Tables 4, 5 and 6).

\subsection{Group-subgroup relationship}

The structural relationship between the bixbyite-type $\mathrm{Cu}_{3}^{\mathrm{II}} \mathrm{Te}^{\mathrm{VI}} \mathrm{O}_{6}-1 C$ aristotype and the $\mathrm{Cu}_{3}{ }_{3} \mathrm{Te}^{\mathrm{VI}} \mathrm{O}_{6}-2 O$ hettotype can be concisely expressed by using a 'Bärnighausen family tree' (Bärnighausen, 1980; Müller, 2004, 2017). Corresponding relationships between Wyckoff positions and coordinates were

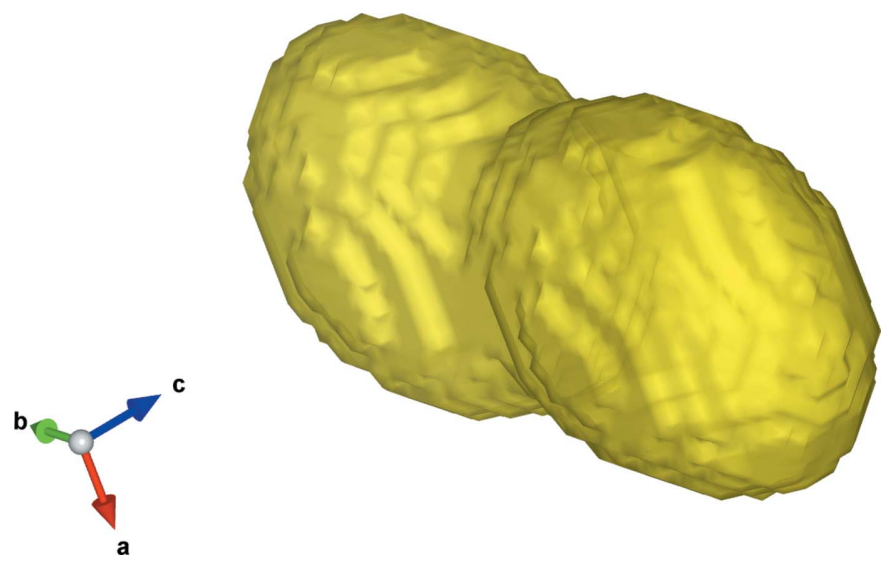

Figure 10

Visualization of the average crystallite size $(20 \times 13.5 \times 64.5 \mathrm{~nm})$ and shape as obtained from the Rietveld refinement shown in Fig. 4. The elongated shape of the average crystallite explains the anisotropic peak shape in the experimental powder pattern. checked and derived with the aid of the program WYCKSPLIT (Kroumova et al., 1998) available at the Bilbao Crystallographic Server (Aroyo et al., 2006).

There is no direct relation between the cubic $\mathrm{Cu}^{\mathrm{II}}{ }_{3} \mathrm{Te}^{\mathrm{VI}} \mathrm{O}_{6}-1 C$ structure $(I a \overline{3}$, No. $206, Z=8)$ and the orthorhombic $\mathrm{Cu}_{3}{ }_{3}^{\mathrm{II}} \mathrm{Te}^{\mathrm{VI}} \mathrm{O}_{6}-2 O$ (Pcca, No. $54, Z=8$ ) structure. Hence, a hypothetical $I$-centred intermediate orthorhombic structure with similar unit-cell parameters $(a, b, c \simeq 9.6 \AA)$ in space group Ibca (No 73, $Z=8$ ) is needed (Fig. 11). The symmetry reduction from the $\mathrm{Cu}_{3}{ }_{3}^{\mathrm{II}} \mathrm{Te}^{\mathrm{VI}} \mathrm{O}_{6}-1 C$ aristotype to the hypothetical structure in space group Ibca is of the translationengleiche type with index 3 ( $\mathrm{t} 3$ ), whereas the symmetry reduction from $I b c a$ to the $\mathrm{Cu}_{3}{ }_{3} \mathrm{Te}^{\mathrm{VI}} \mathrm{O}_{6}-2 O$ hettotype is of the klassengleiche type with index $2(\mathrm{k} 2)$.

As can be seen in Fig. 11, the $\mathrm{Cu} 2$ and $\mathrm{Te} 1$ sites of the hypothetical structure in $\mathrm{Ibca}$ each split into one $\mathrm{Cu}$ and one Te site in the $\mathrm{Cu}_{3}^{\mathrm{II}} \mathrm{Te}^{\mathrm{VI}} \mathrm{O}_{6}-2 O$ structure that give rise to the assumption that sites $\mathrm{Cu} 2$ and $\mathrm{Te} 1$ in the hypothetical structure each could be statistically occupied by the two types of elements. Although the coordination spheres around $\mathrm{Cu}^{\mathrm{II}}$ and $\mathrm{Te}^{\mathrm{VI}}$ usually are distinctly different due to the Jahn-Teller distortion of $\mathrm{Cu}^{\mathrm{II}}$, examples for mixed occupation of $\mathrm{Cu}$ and Te on the same site are known, e.g. in the monoclinic form of $\mathrm{PbCuTeO}_{5}$ (Weil et al., 2019). The symmetry relationships between $\mathrm{Cu}_{3}{ }_{3} \mathrm{Te}^{\mathrm{VI}} \mathrm{O}_{6}-1 C$ and $\mathrm{Cu}_{3}{ }_{3} \mathrm{Te}^{\mathrm{VI}} \mathrm{O}_{6}-2 O$ (including a hypothetical intermediate structure) make it obvious that a direct structural transformation of $\mathrm{Cu}_{3}^{\mathrm{II}} \mathrm{Te}^{\mathrm{VI}} \mathrm{O}_{6}-1 C$ into $\mathrm{Cu}_{3}^{\mathrm{II}} \mathrm{Te}^{\mathrm{VI}} \mathrm{O}_{6}-2 \mathrm{O}$ and vice versa is not possible because this requires a complete reorganization of some of the $\mathrm{Cu}$ and $\mathrm{Te}$ positions.

As shown, the group-subgroup relationship between the cubic aristotype and the orthorhombic hettotype of $\mathrm{Cu}_{3}^{\mathrm{II}} \mathrm{Te}^{\mathrm{VI}} \mathrm{O}_{6}$ requires an intermediate hypothetical structure. However, this does not rule out that other crystal structures for phases with composition $\mathrm{Cu}_{3}{ }_{3}^{\mathrm{II}} \mathrm{Te}^{\mathrm{VI}} \mathrm{O}_{6}$ also could exist, e.g. with a different stacking arrangement or with stacking faults of the $A, B$ layers.
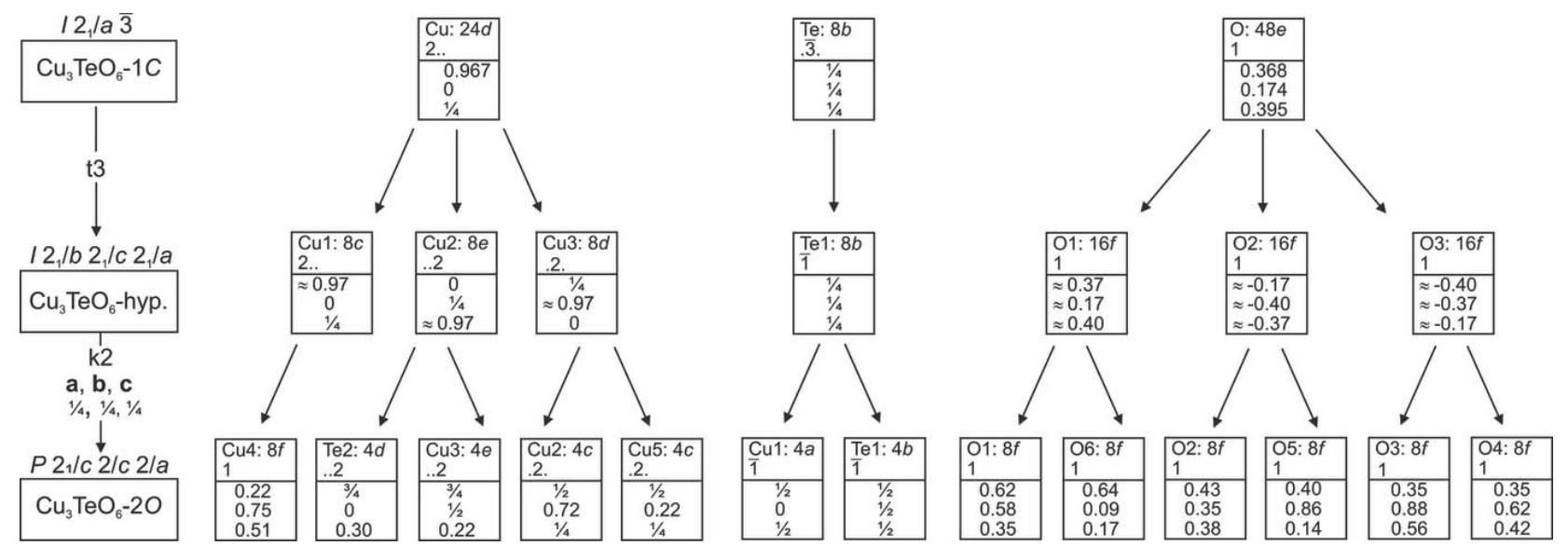

Figure 11

Bärnighausen family tree showing the group-subgroup relationships between the bixbyite-type cubic aristotype structure of $\mathrm{Cu}_{3}^{\mathrm{II}} \mathrm{Te}^{\mathrm{VI}} \mathrm{O}_{6}-1 C$, a hypothetical intermediate structure and the orthorhombic hettotype structure of $\mathrm{Cu}^{\mathrm{II}}{ }_{3} \mathrm{Te}^{\mathrm{VI}} \mathrm{O}_{6}-2 O$. Atomic coordinates of $\mathrm{Cu}^{\mathrm{II}}{ }_{3} \mathrm{Te}^{\mathrm{VI}} \mathrm{O}_{6}-1 C$ were taken from Falck et al. (1978), atomic coordinates of $\mathrm{Cu}_{3}{ }_{3} \mathrm{Te}^{\mathrm{VI}} \mathrm{O}_{6}-2 O$ from the current refinement. 


\subsection{Further observations}

XRPD scans of all the natural $\mathrm{Cu}_{3}{ }_{3} \mathrm{Te}^{\mathrm{VI}} \mathrm{O}_{6}$ samples analysed in this study revealed them to be $\mathrm{Cu}_{3}^{\mathrm{II}} \mathrm{Te}^{\mathrm{VI}} \mathrm{O}_{6}-2 O$, sometimes with extra minor reflections, probably from other minerals incorporated as microinclusions in the $\mathrm{Cu}_{3}{ }_{3} \mathrm{Te}^{\mathrm{VI}} \mathrm{O}_{6}$ coatings. The vast majority of low-temperature hydrothermal syntheses produced $\mathrm{Cu}_{3}{ }_{3} \mathrm{Te}^{\mathrm{VI}} \mathrm{O}_{6}-2 \mathrm{O}$, with the exception of two evaporative hydrothermal syntheses, which produced $\mathrm{Cu}_{3}{ }_{3} \mathrm{Te}^{\mathrm{VI}} \mathrm{O}_{6}-1 C$. $\mathrm{Cu}_{3}{ }_{3} \mathrm{Te}^{\mathrm{VI}} \mathrm{O}_{6}-2 O$ was the only product in several syntheses using $\mathrm{Cu}$ :Te ratios of $6: 1$, with excess $\mathrm{Cu}^{\text {II }}$ seemingly remaining soluble and no additional phases detected in the powder X-ray diffraction patterns. The lack of competing products co-crystallizing in the second batch of experiments led to greater purity of products, even following washing to remove soluble phases. These observations allow the following conclusions to be drawn: (1) mild hydrothermal conditions favour the formation of $\mathrm{Cu}^{\mathrm{II}}{ }_{3} \mathrm{Te}^{\mathrm{VI}} \mathrm{O}_{6}-2 O$, especially when water remains in the system and (2) rapid evaporation of the solvent may promote the formation of $\mathrm{Cu}_{3}^{\mathrm{II}} \mathrm{Te}^{\mathrm{VI}} \mathrm{O}_{6}-1 C$ at temperatures below $473 \mathrm{~K}$, providing one explanation for the possible formation of $\mathrm{Cu}_{3}{ }_{3} \mathrm{Te}^{\mathrm{VI}} \mathrm{O}_{6}-1 C$ from the Gambatesa mine (Carbone et al., 2013). Analysis of the data presented by Carbone et al. (2013) shows that, at the very least, their natural $\mathrm{Cu}_{3}{ }_{3} \mathrm{Te}^{\mathrm{VI}} \mathrm{O}_{6}-1 C$ was intermixed with $\mathrm{Cu}_{3}{ }_{3} \mathrm{Te}^{\mathrm{VI}} \mathrm{O}_{6}-2 O$. For instance, Carbone et al. (2013) present a Raman spectrum for mcalpineite with a broad double maximum (as determined for $\mathrm{Cu}_{3}{ }_{3} \mathrm{Te}^{\mathrm{VI}} \mathrm{O}_{6}-2 O$ in this study) and noted a $d$-spacing at $4.25 \AA$ in their ED experiment from an 'impurity' phase. This $4.25 \AA$ $d$-spacing is present in all $\mathrm{Cu}_{3}{ }_{3} \mathrm{Te}^{\mathrm{VI}} \mathrm{O}_{6}-2 O$ XRPD scans but is not observed for the $1 C$ polytype.

Conversion from $\mathrm{Cu}_{3}{ }_{3} \mathrm{Te}^{\mathrm{VI}} \mathrm{O}_{6}-1 C$ to $\mathrm{Cu}_{3}{ }_{3} \mathrm{Te}^{\mathrm{VI}} \mathrm{O}_{6}-2 O$ does not readily occur. A sample of $\mathrm{Cu}_{3}{ }_{3} \mathrm{Te}^{\mathrm{VI}} \mathrm{O}_{6}-1 C$ was heated at $473 \mathrm{~K}$ under hydrothermal conditions for five days, after which the powder diffraction pattern showed no changes, even though these conditions produce $\mathrm{Cu}_{3}{ }_{3} \mathrm{Te}^{\mathrm{VI}} \mathrm{O}_{6}-2 O$ when synthesized directly from $\mathrm{Cu}^{\mathrm{II}}$ and $\mathrm{Te}^{\mathrm{VI}}$ sources (as discussed).

\subsection{Raman and IR spectroscopy}

The dominant feature of all IR and Raman spectra relates to the $\mathrm{Te}-\mathrm{O}$ stretching band(s). The Raman spectrum of $\mathrm{Cu}_{3}{ }_{3} \mathrm{Te}^{\mathrm{VI}} \mathrm{O}_{6}-2 \mathrm{O}$ features a broad, strong double maximum with bands at 693 and $741 \mathrm{~cm}^{-1}$, whereas the spectrum of CVT-generated crystals of $\mathrm{Cu}_{3}^{\mathrm{II}} \mathrm{Te}^{\mathrm{VI}} \mathrm{O}_{6}-1 C$ contains a single strong maximum centred on $730 \mathrm{~cm}^{-1}$. The broad double maximum is likely related to the lower symmetry of the $\mathrm{Cu}_{3}{ }_{3} \mathrm{Te}^{\mathrm{VI}} \mathrm{O}_{6}-2 \mathrm{O}$ polytype, which contains a range of $\mathrm{Te}-\mathrm{O}$ bond lengths rather than the single $\mathrm{Te}-\mathrm{O}$ bond length in $\mathrm{Cu}_{3}{ }_{3} \mathrm{Te}^{\mathrm{VI}} \mathrm{O}_{6}-1 C$. The higher fidelity of the spectrum collected on $\mathrm{Cu}_{3}{ }_{3}^{\mathrm{II}} \mathrm{Te}^{\mathrm{VI}} \mathrm{O}_{6}-1 C$ shows many smaller bands which are not discernible for $\mathrm{Cu}_{3}{ }_{3} \mathrm{Te}^{\mathrm{VI}} \mathrm{O}_{6}-2 O$, although more bands between 200 and $500 \mathrm{~cm}^{-1}$ might be expected if a higher signal to noise ratio were achieved. The bands at $674,655,621$ and $545 \mathrm{~cm}^{-1}$ are likely to be related to less prominent stretching vibrations (including antisymmetric stretching) of $\mathrm{Te}-\mathrm{O}$ bonds, while those below $500 \mathrm{~cm}^{-1}$ are expected to be related to $\mathrm{Cu}-\mathrm{O}$ modes and symmetric and antisymmetric $\mathrm{Te}-\mathrm{O}$ bending modes. The Raman spectrum of mcalpineite from Bird Nest drift shows a marked similarity to $\mathrm{Cu}_{3}{ }_{3} \mathrm{Te}^{\mathrm{VI}} \mathrm{O}_{6}-2 O$, with a broad double maximum related to the $\mathrm{Te}-\mathrm{O}$ stretching modes. The bands for this feature are at 696 and $743 \mathrm{~cm}^{-1}$, within $5 \mathrm{~cm}^{-1}$ of the bands generated by synthetic $\mathrm{Cu}_{3}{ }_{3} \mathrm{Te}^{\mathrm{VI}} \mathrm{O}_{6}-2 O$. Mcalpineite from the Gambatesa mine (Carbone et al., 2013) also shows the double maximum bands, again indicating the presence of $\mathrm{Cu}_{3}{ }_{3} \mathrm{Te}^{\mathrm{VI}} \mathrm{O}_{6}-2 O$ from this locality rather than only $\mathrm{Cu}_{3}{ }_{3} \mathrm{Te}^{\mathrm{VI}} \mathrm{O}_{6}-1 C$. No features were observed between 4000 and $1100 \mathrm{~cm}^{-1}$ in the Raman spectra for either polytype of $\mathrm{Cu}_{3}^{\mathrm{II}} \mathrm{Te}^{\mathrm{VI}} \mathrm{O}_{6}$ (natural or synthetic).

Scans on $\mathrm{Cu}_{3}^{\mathrm{II}} \mathrm{Te}^{\mathrm{VI}} \mathrm{O}_{6}-1 C$ whether produced by solid-state synthesis or CVT have near-identical IR spectra. However, unlike the Raman spectra, the IR spectra show significant variation when comparing $\mathrm{Cu}_{3}{ }_{3} \mathrm{Te}^{\mathrm{VI}} \mathrm{O}_{6}-2 O$ to $\mathrm{Cu}_{3}{ }_{3} \mathrm{Te}^{\mathrm{VI}} \mathrm{O}_{6}-1 C$ between 4000 and $1600 \mathrm{~cm}^{-1}$. $\mathrm{Cu}_{3}^{\mathrm{II}} \mathrm{Te}^{\mathrm{VI}} \mathrm{O}_{6}-1 C$ shows no significant features in this region (spectra have minor oscillation, but no bands), but $\mathrm{Cu}_{3}{ }_{3} \mathrm{Te}^{\mathrm{VI}} \mathrm{O}_{6}-2 \mathrm{O}$ has a moderately strong, broad absorbance centred on $\sim 3380 \mathrm{~cm}^{-1}$ and a weak mode at $\sim 1639 \mathrm{~cm}^{-1}$. Although these bands are characteristic of the stretching and bending modes, respectively, of $\mathrm{H}_{2} \mathrm{O}$, there are no cavities within $\mathrm{Cu}_{3}^{\mathrm{II}} \mathrm{Te}^{\mathrm{VI}} \mathrm{O}_{6}-2 \mathrm{O}$ suitable for the presence of structural $\mathrm{H}_{2} \mathrm{O}$. It is thus most likely that the water is adsorbed on the surface of $\mathrm{Cu}_{3}^{\mathrm{II}} \mathrm{Te}^{\mathrm{VI}} \mathrm{O}_{6}-2 \mathrm{O}$ granules, resulting in broad bands due to ill-defined water environments. In the region between 1000 and $370 \mathrm{~cm}^{-1}$, each IR spectrum contains five bands, three in the $\mathrm{Te}-\mathrm{O}$ stretching region and two in the $\mathrm{Te}-\mathrm{O}$ bending region. The three stretching region band positions are strong, sharp and nearidentical for the two $\mathrm{Cu}_{3}^{\mathrm{II}} \mathrm{Te}^{\mathrm{VI}} \mathrm{O}_{6}-1 C$ samples (CVT bands at 706,673 and $638 \mathrm{~cm}^{-1}$; solid-state spectrum has bands within

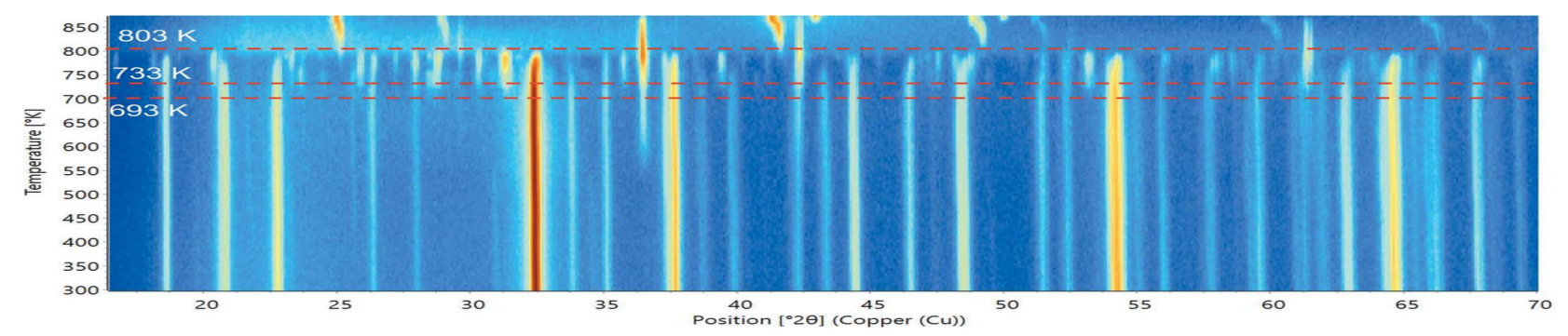

Figure 12

Temperature-dependent XRPD scans of synthetic $\mathrm{Cu}^{\mathrm{II}}{ }_{3} \mathrm{Te}^{\mathrm{VI}} \mathrm{O}_{6}-2 O$, with temperature $(\mathrm{K})$ on the vertical axis plotted against $2 \theta\left(^{\circ}\right)$ on the horizontal axis. Phase transitions are marked with red lines. 
Table 5

Selected bond lengths (in $\AA$ ) for $\mathrm{Cu}_{3}^{\mathrm{II}} \mathrm{Te}^{\mathrm{VI}} \mathrm{O}_{6}-2 O$ as determined by $3 \mathrm{D}$ ED (regular text) and Rietveld (in italics) refinement.

\begin{tabular}{|c|c|c|c|c|c|}
\hline & 3D ED & Rietveld & & 3D ED & Rietveld \\
\hline $\mathrm{Cu} 1-\mathrm{O} 5(\times 2)$ & 2.177 (17) & $2.244(10)$ & $\mathrm{Cu} 5-\mathrm{O} 6(\times 2)$ & $2.04(2)$ & $1.976(14)$ \\
\hline $\mathrm{Cu} 1-\mathrm{O} 6(\times 2)$ & $2.34(2)$ & 2.169 (13) & $\mathrm{Cu} 5-\mathrm{O} 3(\times 2)$ & $2.496(17)$ & $2.360(14)$ \\
\hline$\langle\mathrm{Cu} 1-\mathrm{O}\rangle_{\text {long }}$ & 2.336 & 2.244 & $\langle\mathrm{Cu} 5-\mathrm{O}\rangle_{\text {long }}$ & 2.496 & 2.360 \\
\hline $\mathrm{Cu} 2-\mathrm{O} 5(\times 2)$ & $2.002(18)$ & $1.885(10)$ & $\mathrm{Te} 1-\mathrm{O} 4(\times 2)$ & $1.969(14)$ & $1.965(8)$ \\
\hline \multirow[t]{2}{*}{$\langle\mathrm{Cu} 2-\mathrm{O}\rangle_{\text {long }}$} & 2.398 & 2.545 & & & \\
\hline & & & $\mathrm{Te} 2-\mathrm{O} 6(\times 2)$ & $1.90(2)$ & $1.988(13)$ \\
\hline $\mathrm{Cu} 3-\mathrm{O} 1(\times 2)$ & $1.991(16)$ & 1.937 (13) & $\mathrm{Te} 2-\mathrm{O} 3(\times 2)$ & $2.037(18)$ & $2.096(13)$ \\
\hline $\mathrm{Cu} 3-\mathrm{O} 4(\times 2)$ & $2.050(16)$ & $1.940(12)$ & $\mathrm{Te} 2-\mathrm{O} 5(\times 2)$ & $2.089(16)$ & 1.989 (11) \\
\hline $\mathrm{Cu} 3-\mathrm{O} 2(\times 2)$ & $2.483(16)$ & $2.397(14)$ & $\langle\mathrm{Te} 2-\mathrm{O}\rangle$ & 2.009 & 2.024 \\
\hline$\langle\mathrm{Cu} 3-\mathrm{O}\rangle_{\text {short }}$ & 2.021 & 1.939 & & & \\
\hline $\mathrm{Cu} 4-\mathrm{O} 2$ & $2.113(18)$ & 1.998 (15) & & & \\
\hline $\mathrm{Cu} 4-\mathrm{O} 1$ & $2.387(16)$ & $2.372(14)$ & & & \\
\hline $\mathrm{Cu} 4-\mathrm{O} 6$ & $2.43(2)$ & 2.335 (13) & & & \\
\hline$\langle\mathrm{Cu} 4-\mathrm{O}\rangle_{\text {short }}$ & 2.026 & 1.985 & & & \\
\hline$\langle\mathrm{Cu} 4-\mathrm{O}\rangle_{\text {long }}$ & 2.407 & 2.394 & & & \\
\hline
\end{tabular}

$5 \mathrm{~cm}^{-1}$ of these values) and a higher-energy triplicate peak for $\mathrm{Cu}_{3}^{\mathrm{II}} \mathrm{Te}^{\mathrm{VI}} \mathrm{O}_{6}-2 O\left(665,634\right.$ and $\left.592 \mathrm{~cm}^{-1}\right)$. All of the IR spectra have small absorbance bands between 2000 and $2500 \mathrm{~cm}^{-1}$ (resulting from absorption of the used ATR diamond), but no components of $\mathrm{Cu}_{3}^{\mathrm{II}} \mathrm{Te}^{\mathrm{VI}} \mathrm{O}_{6}$ would be expected to produce bands in this region.

\subsection{Thermal analysis}

Thermogravimetric analysis suggested the loss of $\sim 1.8 \%$ mass from the sample of synthetic $\mathrm{Cu}_{3}{ }_{3} \mathrm{Te}^{\mathrm{VI}} \mathrm{O}_{6}-2 O$ used in the analysis, though this mass loss is less than $50 \%$ of what would be required for stoichiometric loss of one $\mathrm{H}_{2} \mathrm{O}$ molecule per formula unit (e.g. $4.2 \%$ mass loss for theoretical $\mathrm{Cu}_{3}{ }_{3-}$ $\mathrm{Te}^{\mathrm{VI}} \mathrm{O}_{6} \cdot \mathrm{H}_{2} \mathrm{O}$ ). Based on structural and IR considerations, it is most likely that the water associated with the mass loss was adsorbed, rather than structural. $\mathrm{Cu}_{3}{ }_{3} \mathrm{Te}^{\mathrm{VI}} \mathrm{O}_{6}-2 \mathrm{O}$ decomposes in a series of steps (Fig. 12). DSC revealed several transformations as $\mathrm{Cu}_{3}^{\mathrm{II}} \mathrm{Te}^{\mathrm{VI}} \mathrm{O}_{6}-2 \mathrm{O}$ is heated (Fig. 13). A small exothermic event is followed by an endothermic event centred on $673 \mathrm{~K}$, without any obvious XRPD changes. The powder pattern remains virtually constant up until $728 \mathrm{~K}$ when new reflections start to become visible, although an exothermic change begins to occur earlier (at $693 \mathrm{~K}$ ) and continues until $733 \mathrm{~K}$ (Fig. 12). New phases to develop between $728 \mathrm{~K}$ and $803 \mathrm{~K}$ include $\mathrm{Cu}_{2} \mathrm{O}$ (ICDD code 04-007-9767) and orthorhombic $\mathrm{CuTeO}_{3}$ (balyakinite, 01-071-2230). Their formation is an exothermic process. Thermodynamically, following the exothermic change, no significant feature occurs until $763 \mathrm{~K}$, when endothermic change occurs until $803 \mathrm{~K}$ (Fig. 13). Above $808 \mathrm{~K}, \mathrm{Cu}_{2} \mathrm{O}$ is dominant, and is found along with cubic $\mathrm{Cu}_{2} \mathrm{Te}$ (01-082-4898; 01-082-4898). A final XRPD scan was collected following cooling back to $303 \mathrm{~K}$, showing hexagonal $\mathrm{Cu}_{2} \mathrm{Te}$ (weissite, 04-019-1996) without any evidence of $\mathrm{Cu}_{2} \mathrm{O}$. The decomposition of $\mathrm{Cu}_{3}{ }_{3} \mathrm{Te}^{\mathrm{VI}} \mathrm{O}_{6}-2 \mathrm{O}$ may proceed by the following two-step process, although it is worth noting that amorphous $\mathrm{Cu}-\mathrm{Te}-\mathrm{O}$ phases may also constitute some of the high-temperature decomposition products, potentially lowering the amount of $\mathrm{O}$ released during the decomposition:

(1) $\mathrm{Cu}_{3}{ }_{3} \mathrm{Te}^{\mathrm{VI}} \mathrm{O}_{6}(\mathrm{~s}) \rightarrow \mathrm{Cu}^{\mathrm{II}} \mathrm{Te}^{\mathrm{IV}} \mathrm{O}_{3}(\mathrm{~s})+\mathrm{Cu}_{2}{ }_{2} \mathrm{O}(\mathrm{s})+\uparrow \mathrm{O}_{2}(\mathrm{~g})$

(2) $\mathrm{Cu}^{\mathrm{II}} \mathrm{Te}^{\mathrm{IV}} \mathrm{O}_{3}$ (s) $+\mathrm{Cu}_{2}^{\mathrm{I}} \mathrm{O}(\mathrm{s}) \rightarrow \mathrm{Cu}_{2} \mathrm{Te}$ (s, cubic) + $0.5 \mathrm{Cu}_{2}^{\mathrm{I}} \mathrm{O}(\mathrm{s})+\uparrow 1.75 \mathrm{O}_{2}(\mathrm{~g})$

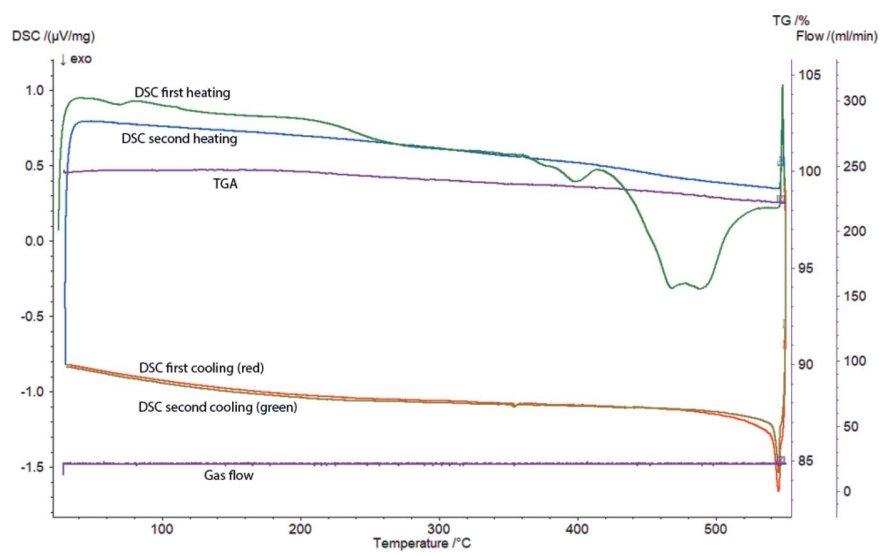

Figure 13

TGA and DSC traces of synthetic $\mathrm{Cu}_{3}{ }_{3} \mathrm{Te}^{\mathrm{VI}} \mathrm{O}_{6}-2 O$. TGA trace is in purple. Two cycles of DSC begin with the bright-green line (first heating), red line (first cooling), blue line (second heating), dull-green line near overlying the red line (second cooling). 
Table 6

Bond valences for $\mathrm{Cu}_{3}{ }_{3} \mathrm{Te}^{\mathrm{VI}} \mathrm{O}_{6}-2 \mathrm{O}$ using bond lengths from the $3 \mathrm{D}$ ED refinement.

Sums for Rietveld are also shown in the table in italics. Bond-valence parameters taken from Gagné \& Hawthorne (2015) for $\mathrm{Cu}-\mathrm{O}$ bonds and Mills \& Christy (2013) for $\mathrm{Te}^{\mathrm{VI}}-\mathrm{O}$ bonds.

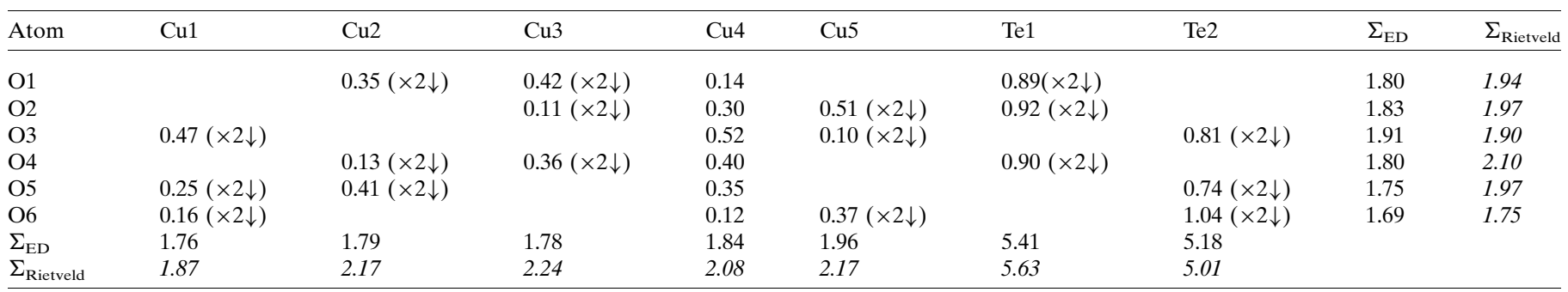

\subsection{Observations in the $\mathrm{Cu}^{\prime \prime}-\mathrm{Te}^{\mathrm{VI}}-\mathrm{O}-\mathrm{H} \pm$ system}

$\mathrm{Cu}_{3}{ }_{3}^{\mathrm{II}} \mathrm{Te}^{\mathrm{VI}} \mathrm{O}_{6}$ is highly stable across a wide range of conditions and with a wide variety of other compounds. $\mathrm{Cu}_{3}{ }_{3} \mathrm{Te}^{\mathrm{VI}} \mathrm{O}_{6}$ was hydrothermally synthesized across a $\mathrm{pH}$ range of 0 to 14 and was encountered (not necessarily in a pure form) with a wide variety of counter-cations and counter-anions, including $\mathrm{Na}^{+}, \mathrm{K}^{+}, \mathrm{Ag}^{+}, \mathrm{Pb}^{2+}, \mathrm{CO}_{3}{ }^{2-}, \mathrm{NO}_{3}{ }^{-}, \mathrm{SO}_{4}{ }^{2-}$ and $\mathrm{Cl}^{-}$.

Additional impure samples of $\mathrm{Cu}_{3}^{\mathrm{II}} \mathrm{Te}^{\mathrm{VI}} \mathrm{O}_{6}$ were also generated from syntheses initially incorporating $\mathrm{TeO}_{2}$. Oxidation of $\mathrm{Te}^{\mathrm{IV}}$ in $\mathrm{TeO}_{2}$ to $\mathrm{Te}^{\mathrm{VI}}$ occurred in both hightemperature solid-state syntheses and in hydrothermal syntheses in which dehydration occurred, but never in hydrothermal syntheses in which water remained. Oxidation presumably occurred with atmospheric oxygen as the oxidant.

\section{8. $\mathrm{Cu}^{\mathrm{II}}{ }_{3} \mathrm{Te}^{\mathrm{VI}} \mathrm{O}_{6}$ as a sink for other cations}

The results of the EPMA analysis of Millsite Boulder mcalpineite from Norway are (oxide, average, min-max, standard deviation): $\mathrm{Cu}$ ( $\mathrm{CuO}, 45.40,41.53-48.77,2.3)$, Te $\left(\mathrm{TeO}_{3}, 41.51,40.87-42.52,0.6\right)$ and $\mathrm{U}\left(\mathrm{UO}_{2}, 9.62,6.62-12.90\right.$, 2.1). The data lead to a somewhat low analytical total of $96.54 \mathrm{wt} \%$, attributed to the heterogeneous nature of the mcalpineite (porous and formed from crystals $<1 \mu \mathrm{m}$ in size). The empirical formula is $\mathrm{Cu}_{2.53} \mathrm{U}_{0.16} \mathrm{Te}_{1.05} \mathrm{O}_{6.00}$ and the simplified formula is $\left(\mathrm{Cu}^{\mathrm{II}}{ }_{2.53} \mathrm{U}^{\mathrm{IV}}{ }_{0.16} \mathrm{Te}^{\mathrm{VI}}{ }_{0.11}\right)_{\Sigma 2.80} \mathrm{Te}^{\mathrm{VI}}{ }_{0.94} \mathrm{O}_{6}$, based on six $\mathrm{O}$ anions per formula unit, showing $>5$ at $\% \mathrm{U}^{\mathrm{IV}}$ substitution of $\mathrm{Cu}^{\mathrm{II}}$ compared to the ideal formula, $\mathrm{Cu}_{3-}{ }_{3-}$ $\mathrm{Te}^{\mathrm{VI}} \mathrm{O}_{6}$. It is worth noting that this substitution requires vacancies in the crystal structure to maintain charge balance, though less vacancies than if $\mathrm{U}^{\mathrm{VI}}$ were to substitute for $\mathrm{Cu}^{\mathrm{II}}$. We postulate that the $\mathrm{U}^{\mathrm{IV}}$ is able to substitute for $\mathrm{Cu}^{\mathrm{II}}$ as JahnTeller distorted $\mathrm{Cu}^{\text {II }}$ cations (average $\mathrm{Cu}-\mathrm{O}$ bond length in mcalpineite-2O 2.111 $\AA$ ) provide more space for the larger $\mathrm{U}^{\mathrm{IV}}$ cations than regular $\mathrm{Te}^{\mathrm{VI}}$ octahedra $(\mathrm{Te}-\mathrm{O}$ average $1.991 \AA$ ). While $\mathrm{Te}^{\mathrm{VI}-\mathrm{U}^{\mathrm{VI}}}$ substitution has been observed in the mineral markcooperite $\left(\mathrm{PbUO}_{2} \mathrm{Te}^{\mathrm{VI}} \mathrm{O}_{6}\right)$, which has a mixed $\mathrm{U}^{\mathrm{VI}}: \mathrm{Te}^{\mathrm{VI}}$ site in a 75:25\% ratio (Kampf et al., 2010), the EPMA data suggest that $\mathrm{U}^{\mathrm{IV}}$ substitutes for $\mathrm{Cu}^{\mathrm{II}}$ in this case.

These results indicate that mcalpineite might be a sink for $U$ in $\mathrm{Cu}$ - and Te-rich weathering zones, an observation that may have significance in the area of nuclear remediation. Radioactive isotopes of Te including ${ }^{132} \mathrm{Te}$ and ${ }^{129 \mathrm{~m}} \mathrm{Te}$ are released by nuclear fission, meaning that these isotopes must be accounted for in remediation of sites such as Fukushima Daiichi following the nuclear power plant disaster in 2011 (Dickson \& Glowa, 2019; Tagami et al., 2013; Takahashi et al., 2019). U-bearing mcalpineite could be used to entrap both Te and $U$ due to its high stability over the full $\mathrm{pH}$ range (as shown by our syntheses of $\mathrm{Cu}_{3}{ }_{3} \mathrm{Te}^{\mathrm{VI}} \mathrm{O}_{6}$ ) and its ability to incorporate both elements. $\mathrm{Cu}_{3}{ }_{3}^{\mathrm{II}} \mathrm{Te}^{\mathrm{VI}} \mathrm{O}_{6}$ may also incorporate other cations into its structure, including $\mathrm{Zn}$ (5 at\% substitution for $\mathrm{Cu}$, Centennial Eureka Mine; Roberts et al., 1994) and $\mathrm{Pb}$ (3 at\% substitution for $\mathrm{Cu}$ at McAlpine mine; Roberts et al., 1994) in cotype material. Incorporation of $\mathrm{Pb}$ into mcalpineite appears to be relatively common, with 3 at $\% \mathrm{~Pb}$ substitution for $\mathrm{Cu}$ observed in mcalpineite from Delamar and 6 at $\% \mathrm{~Pb}$ from Otto Mountain in SEM in this study, showing the versatility of the $\mathrm{Cu}_{3}{ }_{3} \mathrm{Te}^{\mathrm{VI}} \mathrm{O}_{6}-2 \mathrm{O}$ structure. Future studies should quantify the ability of mcalpineite to incorporate different cations.

\section{9. $\mathrm{Cu}_{3} \mathrm{TeO}_{6}$ polytypes in Nature}

The mineral mcalpineite consists of two polytypes of $\mathrm{Cu}_{3}{ }_{3} \mathrm{Te}^{\mathrm{VI}} \mathrm{O}_{6}$, with the entirety of the North American specimens, all collected from weathering zone Te-O mineral assemblages, consisting of mcalpineite-2O. The only localities where pure mcalpineite- $1 C$ is likely to be formed naturally are high-temperature oxidizing fumaroles (as opposed to the apparent mixture of mcalpineite polytypes at the weathering zone of the Gambatesa mine, Italy). Mcalpineite has been reported from one fumarole to date (Pekov et al., 2019), the Arsenatnaya fumarole, Second scoria cone, Tolbachik Volcano, Kamchatka Krai, Russia $\left(55.68333^{\circ} \mathrm{N}, 160.23333^{\circ} \mathrm{E}\right.$; Pekov et al., 2018). Mcalpineite was found in amounts insufficient for collecting a powder X-ray diffraction scan (Pekov et $a l ., 2019)$. It is likely that this mcalpineite is mcalpineite- $1 C$, pending future confirmation by either XRPD or Raman spectroscopy.

\section{Acknowledgements}

We thank Professor Janusz Lipkowski for handling our manuscript and two anonymous reviewers for their helpful and insightful comments. Support funding has been provided to OPM by an Australian Government Research Training 
Program (RTP) Scholarship, a Monash Graduate Excellence Scholarship (MGES) and a Robert Blackwood MonashMuseums Victoria scholarship. The authors acknowledge use of the facilities within the Monash Centre for Electron Microscopy. OPM thanks TU Wien for extending the invitation to spend a portion of his PhD research in Vienna. Part of this study has been funded by the Ian Potter Foundation grant "Tracking Tellurium" (to SJM) and by the John Jago Trelawney Endowment to the Mineral Sciences Department of the Natural History Museum of Los Angeles County (to ARK).

\section{References}

Aroyo, M. I., Perez-Mato, J. M., Capillas, C., Kroumova, E., Ivantchev, S., Madariaga, G., Kirov, A. \& Wondratschek, H. (2006). Z. Kristallogr. 221, 15-27.

Atencio, D., Roberts, A. C., Matioli, P. A., Stirling, J. A. R., Venance, K. E., Doherty, W., Stanley, C. J., Rowe, R., Carpenter, G. J. C. \& Coutinho, J. M. V. (2008). Mineral. Mag. 72, 1201-1205.

Bärnighausen, H. (1980). MATCH. Commun. Math. Chem. 9, 139175.

Binnewies, M., Glaum, R., Schmidt, M. \& Schmidt, P. (2012). Chemical Vapor Transport Reactions. DeGruyter, Berlin, Germany.

Carbone, C., Basso, R., Cabella, R., Martinelli, A., Grice, J. D. \& Lucchetti, G. (2013). Am. Mineral. 98, 1899-1905.

Chakraborty, J. (2019). J. Phys. Chem. Solids, 134, 182-186.

Choi, K., Lemmens, P., Choi, E. \& Berger, H. (2008). J. Phys. Condens. Matter, 20, 505214.

Christy, A. G., Mills, S. J. \& Kampf, A. R. (2016b). Mineral. Mag. 80, 415-545.

Christy, A. G., Mills, S. J., Kampf, A. R., Housley, R. M., Thorne, B. \& Marty, J. (2016a). Mineral. Mag. 80, 291-310.

Dickson, R. S. \& Glowa, G. A. (2019). J. Environ. Radioact. 204, 4965.

Falck, L., Lindqvist, O. \& Moret, J. (1978). Acta Cryst. B34, 896-897. Gagné, O. C. \& Hawthorne, F. C. (2015). Acta Cryst. B71, 562-578.

Gemmi, M., Mugnaioli, E., Gorelik, T. E., Kolb, U., Palatinus, L., Boullay, P., Hovmöller, S. \& Abrahams, J. P. (2019). ACS Cent. Sci. 5, 1315-1329.

He, Z. \& Itoh, M. (2014). J. Magn. Magn. Mater. 354, 146-150.

Herak, M., Berger, H., Prester, M., Miljak, M., Živković, I., Milat, O., Drobac, D., Popović, S. \& Zaharko, O. (2005). J. Phys. Condens. Matter, 17, 7667-7679.

Hostachy, A. \& Coing-Boyat, J. (1968). C. R. Acad. Sci. B267, 14351438.

Housley, R. M., Kampf, A. R., Mills, S. J., Marty, J. \& Thorne, B. (2011). Rocks Min. 86, 132-145.

Inosov, D. (2018). Adv. Phys. 67, 149-252.

Kampf, A. R., Mills, S. J., Housley, R. M., Marty, J. \& Thorne, B. (2010). Am. Mineral. 95, 1554-1559.

Kolb, U., Gorelik, T., Kübel, C., Otten, M. \& Hubert, D. (2007). Ultramicroscopy, 107, 507-513.
Kroumova, E., Perez-Mato, J. M. \& Aroyo, M. I. (1998). J. Appl. Cryst. 31, 646-646.

Mills, S. J. \& Christy, A. G. (2013). Acta Cryst. B69, 145-149.

Müller, U. (2004). Z. Anorg. Allg. Chem. 630, 1519-1537.

Müller, U. (2017). Symmetry Relationships between Crystal Structures. Oxford University Press.

Mutharani, B., Rajakumaran, R., Chen, S.-M., Ranganathan, P., Chen, T.-W., Al Farraj, D. A., Ajmal Ali, M. \& Al-Hemaid, F. M. A. (2020). Microchem. J. 159, 105378.

Nénert, G., Missen, O. P., Lian, H., Weil, M., Blake, G. R., Kampf, A. R. \& Mills, S. J. (2020). Phys. Chem. Miner. 47, 1-8.

Norman, M. R. (2016). Rev. Mod. Phys. 88, 041002.

Norman, M. R. (2018). J. Magn. Magn. Mater. 452, 507-511.

Palatinus, L., Brázda, P., Jelínek, M., Hrdá, J., Steciuk, G. \& Klementová, M. (2019). Acta Cryst. B75, 512-522.

Palatinus, L. \& Chapuis, G. (2007). J. Appl. Cryst. 40, 786-790.

Palmer, D. (2009). CrystalMaker. CrystalMaker Software Ltd. Yarnton, Oxfordshire, England.

Pekov, I. V., Chukanov, N. V., Zadov, A. E., Roberts, A. C., Jensen, M. C., Zubkova, N. V. \& Nikischer, A. J. (2011). Geol. Ore Depos. 53, 575-582.

Pekov, I. V., Koshlyakova, N. N., Zubkova, N. V., Lykova, I. S., Britvin, S. N., Yapaskurt, V. O., Agakhanov, A. A., Shchipalkina, N. V., Turchkova, A. G. \& Sidorov, E. G. (2018). Eur. J. Mineral. 30, 305322.

Pekov, I. V., Turchkova, A. G., Yapaskurt, V. O., Sandalov, F. D. \& Sidorov, E. G. (2019). Miner. Divers. Res. Preserv. 10th Int. Symp. pp. 63-66.

Petrríček, V., Dušek, M. \& Palatinus, L. (2014). Z. Kristallogr. 229, 345-352.

Roberts, A. C., Ercit, T. S., Criddle, A. J., Jones, G. C., Williams, R. S., Cureton, F. F. II \& Jensen, M. C. (1994). Mineral. Mag. 58, 417-424.

Roberts, A. C., Gault, R. A., Jensen, M. C., Criddle, A. J. \& Moffat, E. A. (1997). Mineral. Mag. 61, 139-144.

Roberts, A. C., Grice, J. D., Criddle, A. J., Jensen, M. C., Harris, D. C. \& Moffatt, E. A. (1995). Can. Mineral. 33, 641-647.

Roberts, A. C., Grice, J. D., Groat, L. A., Criddle, A. J., Gault, R. A., Erd, R. C. \& Moffatt, E. A. (1996a). Can. Mineral. 34, 49-54.

Roberts, A. C., Groat, L. A., Grice, J. D., Gault, R. A., Jensen, M. C., Moffatt, E. A. \& Stirling, J. A. (1996b). Mineral. Mag. 60, 653-657.

Roberts, A. C., Stirling, J. A. R., Criddle, A. J., Jensen, M. C., Moffat, E. A. \& Wilson, W. E. (1997). Mineral. Rec. 28, 175.

Rumsey, M. S., Welch, M. D., Mo, F., Kleppe, A. K., Spratt, J., Kampf, A. R. \& Raanes, M. P. (2018). Mineral. Mag. 82, 433-444.

Spek, A. L. (2020). Acta Cryst. E76, 1-11.

Tagami, K., Uchida, S., Ishii, N. \& Zheng, J. (2013). Environ. Sci. Technol. 47, 5007-5012.

Takahashi, S., Kawashima, S., Hidaka, A., Tanaka, S. \& Takahashi, T. (2019). Nucl. Technol. 205, 646-654.

Wang, D., Bo, X., Tang, F. \& Wan, X. (2019). Phys. Rev. B, 99, 035160.

Weil, M., Shirkhanlou, M. \& Stürzer, T. (2019). Z. Anorg. Allg. Chem. 645, 347-353.

Williams, S. A. (1975). Mineral. Mag. 40, 221-226.

Zhu, X., Wang, Z., Su, X. \& Vilarinho, P. M. (2014). Appl. Mater. Interfaces, 6, 11326-11332. 